\title{
Nile Red-Based GPCR Ligands as Ultrasensitive Probes of the Local Lipid Microenvironment of the Receptor
}

\author{
Fabien Hanser, ${ }^{[a]}$ Claire Marsol, ${ }^{[a, b]}$ Christel Valencia, ${ }^{[b]}$ Pascal Villa, ${ }^{[b]}$ Andrey S. Klymchenko, ${ }^{[c]}$ \\ Dominique Bonnet*\#[a] and Iuliia A. Karpenko*\#[a]
}

[a] F. Hanser, Dr. C. Marsol, Dr. D. Bonnet and Dr. I. A. Karpenko, Laboratoire d'Innovation Thérapeutique, LabEx MEDALIS, UMR7200, CNRS/Université de Strasbourg, 74 route du Rhin, 67401 Illkirch-Graffenstaden, France E-mail: i.karpenko@unistra.fr $\underline{\text { dominique.bonnet@unistra.fr }}$

[b] C. Valencia, Dr. P. Villa, Platform of Integrative Chemical Biology of Strasbourg (PCBIS), LabEx MEDALIS, UMS 3286 CNRS/Université de Strasbourg, ESBS Pôle API, Bld Sébastien Brant, 67412 Illkirch-Graffenstaden, France.

[c] Dr. A. S. Klymchenko, Laboratoire de Bioimagerie et Pathologies, UMR 7021 CNRS/Université de Strasbourg, 74 route du Rhin, 67401 Illkirch-Graffenstaden, France.

\# These authors contributed equally to this work.

\begin{abstract}
The local lipid microenvironment of transmembrane receptors is an essential factor in GPCR signaling. However, tools are currently missing for studying endogenously expressed GPCRs in primary cells and tissues. Here we introduce fluorescent environment-sensitive GPCR ligands for probing the microenvironment of the receptor in living cells using fluorescence microscopy under no-wash conditions. We designed and synthesized antagonist ligands of the oxytocin receptor (OTR) by conjugating a high-affinity non-peptidic OTR ligand PF-3274167 to the environment-sensitive fluorescent dye Nile Red. The length of the polar PEG spacer between the pharmacophore and the fluorophore was adjusted to lower the non-specific interactions of the probe while preserving a strong fluorogenic response. We demonstrated that the new probes embed into the lipid bilayer in the vicinity of the receptor and convey the information about the local polarity and the lipid order via the wavelength-shifting emission of the Nile Red fluorophore.
\end{abstract}

\section{Introduction}

G-protein coupled receptors (GPCRs) are a superfamily of transmembrane receptor proteins that are ubiquitously expressed in the human body and widely involved in human physiology and pathophysiology. GPCRs represent the most intensively studied targets for small-molecule therapeutics. For instance, more than 470 (> 30\%) of currently marketed drugs act on over a hundred of unique GPCRs, with hundreds of prospective drugs being in preclinical development and clinical trials. ${ }^{1-4}$ The field of GPCR research had been boosted by the recent breakthrough in the structural biology of transmembrane receptors, which revealed the three-dimensional architecture and conformational dynamics of isolated receptors, receptor-ligand and receptor-transducer protein complexes at an unprecedented atomic-level resolution. These findings gave numerous structural insights into the selectivity of ligand recognition and mechanisms of the signal transduction, facilitating further biochemical and pharmacological exploration of this class of drug targets. ${ }^{5-7}$ Although these advances have opened new avenues for the rational development of GPCR-targeting drugs, we still have only a dim understanding of the GPCR activation and signal transduction in the complex cellular context. GPCRs are embedded into highly heterogeneous and dynamic cellular membranes, where lipid organization and the presence of lipid nanodomains ${ }^{8,9}$ can modulate the functioning of the receptor. To 
fill the gap between the growing body of structural information obtained on purified receptors ex vivo ${ }^{10}$ and understanding their functioning and the heterogeneity of signaling in living cells, a multitude of chemical, pharmacological and optical tools has been developed. ${ }^{11-15}$ Fluorescence-based methods are of particular interest for studying GPCR in their native environment because of their high sensitivity, high spatial and temporal resolution and possibility to apply them in intact living cells and tissues. ${ }^{16,17}$ Besides that, the key advantage of fluorescence sensing is the possibility to directly and site-specifically probe dynamic molecular interactions using environment-sensitive small-molecule fluorescent reporters. ${ }^{18,19}$

Local alterations of the lipid microenvironment, such as the presence of highly organized lipid nanodomains, known as lipid rafts, can affect the conformation equilibrium of the transmembrane receptor, its affinity to ligands and its protein-protein interactions. ${ }^{20-25}$ Therefore, studying the lipid microenvironment of receptors is of fundamental importance for understanding and modulating GPCR signaling. ${ }^{26}$ However, the progress has been hampered by the lack of reliable experimental methods and by the multiple controversies related to the lipid raft hypothesis. ${ }^{27}$ Environment-sensitive probes, such as LAURDAN, ${ }^{28}$ di-4-ANEPPDHQ,${ }^{29}$ Nile Red (NR) derivatives,,${ }^{30,31}$ could be used to address the lipid order in biomembranes through shifts in the emission color ${ }^{32}$ However, these probes report the average lipid order of the bulk of cell membrane and are not suitable for probing specifically the receptor microenvironment. One work addressed probing of the local receptor microenvironment within the Förster radius by using time-resolved FRET from a GLP-1 receptor labeled with a long-life luminescent terbium cryptate to NR-based probe NR12S. ${ }^{33}$ However, studying the local lipid microenvironment of untagged GPCRs in intact living cells and tissues remains a formidable challenge. In our previous works, we synthesized optically-responsive chemical probes targeting the oxytocin receptor (OTR), a class A GPCR. In our design, a peptidic agonist of the receptor was covalently tethered to the NR fluorophore. ${ }^{34}$ The resulting conjugate delivered the fluorescent probe directly into the lipid bilayer in the vicinity of the receptor. Being non-fluorescent in water, the conjugate displayed a strong enhancement of fluorescence upon binding to the receptor, enabling qualitative and quantitative detection of the receptor under wash-free conditions. Although the solvatochromic properties of Nile Red have been successfully used for probing the polarity and molecular organization of biological membranes,,$^{30,31,35,36}$ the utility of our first-generation OTR-targeting fluorescent probes for studying the lipid microenvironment of the native receptors was limited because of their agonism. Binding of the probes to the OTR triggered fast cellular response resulting in the rapid internalization of the receptor which is usually associated with the dramatic changes of lipid composition of the receptor within the endosomal compartment. In the present work, we address these limitations and report a new generation of GPCR-targeting fluorescent probes. To overcome the problem of receptor internalization, we designed, synthesized and characterized a series of antagonist-based conjugate delivering the environment-sensitive fluorogenic Nile Red-based probe into the vicinity of the OTR. We used a combination of steady-state fluorescence spectroscopy and ratiometric confocal fluorescence microscopy to demonstrate the ability of the new probes to embed into the lipid bilayer in the vicinity of the receptor in living cells and to transmit the information about the properties of the local lipid microenvironment via the color-shifting emission of the NR fluorophore. 
A

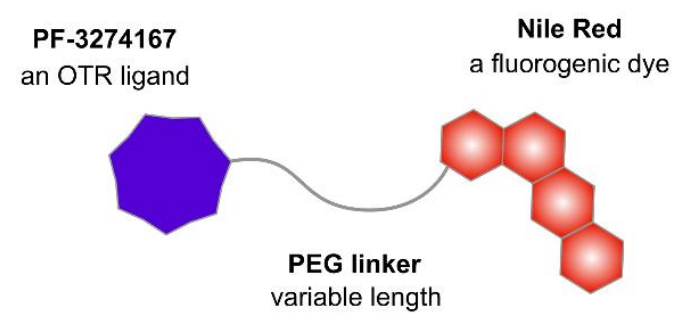

B

non-fluorescent

fluorescent

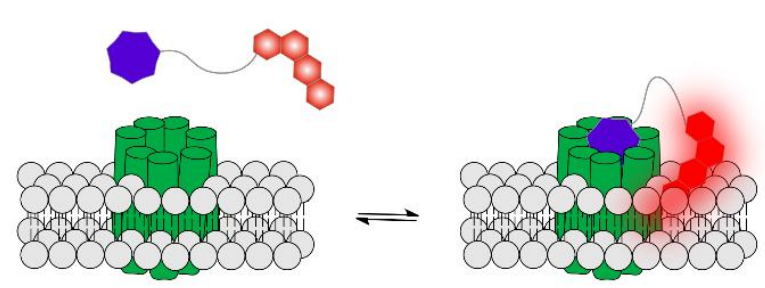

Figure 1. The design (A) and the working principle (B) of the fluorogenic non-peptidic OTR ligands.

\section{Results and Discussion}

Design and Synthesis. To design antagonist-based environment-sensitive conjugates targeting the OTR we used the approach that had been validated on peptidic OTR agonists. ${ }^{34}$ Solvatochromic fluorogenic NR dye was covalently tethered to a non-peptidic antagonist of the OTR via a flexible linker of variable length (Figure 1A). NR-based carboxylic acid NR-COOH (4, Scheme 1) and the desmethyl precursor of the OTR-selective antagonist PF-3274167 37,38 were chosen as the key structural blocks to be conjugated through a flexible polyethylenglycol (PEG)-based tethers of variable length. Four PEG linkers composed of 4-20 ethylenic moieties were selected and tested to decrease the off-target binding of the probes and to finely tune the specificity of the probe and its fluorogenic response upon homogenous wash-free imaging condition (Figure 1B). First, we revised the synthesis of NR-COOH 4 (Scheme 1). The procedure reported in the literature starts from the conversion of commercially available 3-diethylaminophenol 1 into nitrosophenol 2, which is then engaged into an intermolecular oxidative cyclization with 1,6-dihydroxynaphthalene to give the phenol derivative of Nile Red 3 . According to the original protocols, ${ }^{39,40}$ nitrosophenol $\mathbf{2}$ was purified by recrystallization from ethanol/diethyl ether mixture and then refluxed in DMF with 1,6-dihydroxynaphthalene to give the desired compound $\mathbf{3}$ in moderate yield of $42 \%$ over two steps. 

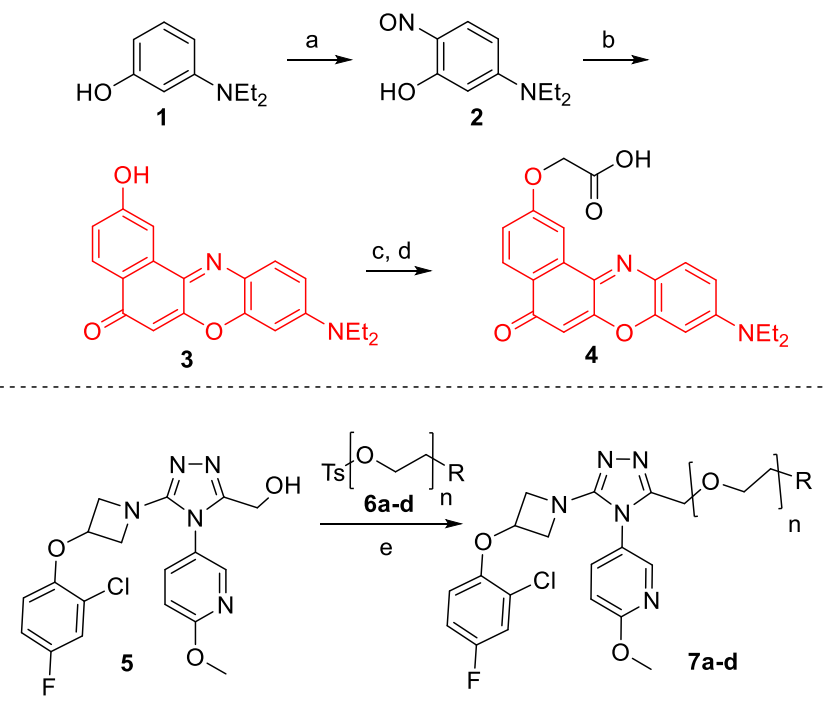

6a, $7 a, n=4, R=\mathrm{NBoc}_{2}$

$6 b, 7 b, n=8, R=\mathrm{NBoc}_{2}$

$6 c, 7 c, n=12, R=N_{3}$

$6 d, 7 d, n=20, R=N_{3}$

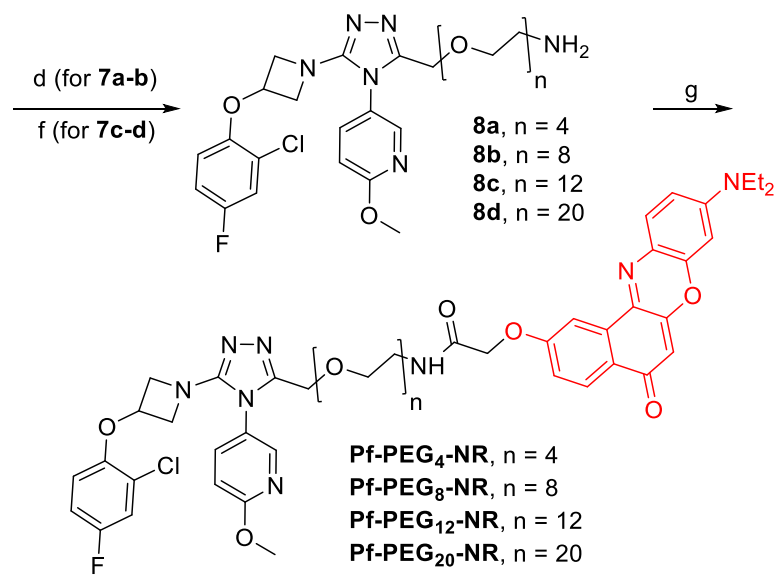

Scheme 1. Synthesis of the non-peptidic fluorescent OTR ligands. a) $\mathrm{NaNO}_{2}, \mathrm{HCl}, \mathrm{H}_{2} \mathrm{O}, 0{ }^{\circ} \mathrm{C}, 2.5$ h. b) 1,6 Dihydroxynaphthalene, DMF, $110{ }^{\circ} \mathrm{C}, 45$ min. c) tert-Butyl chloroacetate, $\mathrm{K}_{2} \mathrm{CO}_{3}$, acetone, reflux, 6.5 h. d) Trifluoroacetic acid, DCM, $25^{\circ} \mathrm{C}, 0.5-3.5$ h. e) KOH, DMF, $0-45^{\circ} \mathrm{C}, 2.5-67$ h. f) Triphenylphosphine polymer-bound, THF, reflux then $\mathrm{H}_{2} \mathrm{O}$, reflux, 5-7 h. g) 4, PyBOP, DIPEA, DMF, $25^{\circ} \mathrm{C}, 0.5-25 \mathrm{~h}$..

However, in our hands the recrystallization of nitrosophenol $\mathbf{3}$ was not robustly reproducible. To make things worse, nitrosophenol was found to decompose upon boiling in DMF, resulting in highly variable and significantly lower yields of Nile Red derivative 3 (27\% at best). We improved the synthetic protocol by omitting the problematic crystallization step. We found that better yields of $\mathbf{3}$ were obtained when the crude nitrosophenol 2 was isolated by evaporation of the acidic reaction mixture and engaged into the cyclization without further purification. The intermolecular cyclization was carried out with 2 equiv. of nitrosophenol 2 in DMF at $110^{\circ} \mathrm{C}$ for $45 \mathrm{~min}$. Following the proposed protocol, the phenol derivative of Nile Red 3 was obtained in $44 \%$ yield over two steps. The protocol was robustly reproducible on 0.45 - 3 mmol scale. Phenol 3 was then alkylated with tert-butyl chloroacetate ${ }^{41}$ and then tert-butyl protecting group was removed by the treatment with trifluoroacetic acid to afford NR$\mathrm{COOH} 4$ in $84 \%$ yield over two steps (Scheme 1). 
The synthesis of the desmethyl precursor of PF-3274167 5 and its two pegylated derivatives 8a and $\mathbf{8 b}$ bearing $\mathrm{PEG}_{4}$ and $\mathrm{PEG}_{8}$ chains (Scheme 1) was performed following our previously established protocols. ${ }^{38}$ Regarding $\mathrm{PEG}_{12}$ and $\mathrm{PEG}_{20}$ derivatives $\mathbf{8 c}$ and $\mathbf{8 d}$, we found it more convenient to synthesize these amines by reducing the corresponding azides. To achieve this, we first alkylated the desmethyl precursor of PF-3274167 5 with azido-tosylates $\mathbf{6 c}$ and $\mathbf{6 d}$ in the presence of $\mathrm{KOH}$ in DMF affording pegylated triazoles $\mathbf{7 c}$ and $\mathbf{7 d}$ in $92 \%$ and $72 \%$ yield, respectively. Next, $\mathbf{7 c}$ and $\mathbf{7 d}$ were converted into amines 8c and 8d using the Staudinger reduction in the presence of polymer-bound triphenylphosphine. Finally, coupling of amines 8a-d to NR-COOH led to the formation of the desired OTR non-peptidic ligands Pf-PEG 4 -NR, Pf-PEG 8 -NR, Pf-PEG $12-\mathrm{NR}$ and Pf-PEG ${ }_{20}-\mathrm{NR}$.

Spectroscopic Characterization. The fluorescence properties of the Nile Red derivatives were first studies in a series of solvents of different polarity. Steady-state fluorescence spectra of the OTR ligands (Figure 2A) revealed that the strong solvatochromic and fluorogenic character of Nile Red was retained upon conjugation of NR-COOH to the OTR ligand via the PEG linkers. All the four OTR ligands were highly fluorescent in apolar solvents such as 1,4-dioxane with the emission maxima of about $585 \mathrm{~nm}$ (Table 1). Due to the positive solvatochromism of Nile Red, the emission maxima in water bathochromically shifted to $660 \mathrm{~nm}$, and the fluorescence quantum yields gradually decreased with the increasing polarity of the solvent.

Table 1. Fluorescence properties of the NR conjugates.

\begin{tabular}{|c|c|c|c|c|c|c|}
\hline \multirow[b]{2}{*}{ Solvent } & \multicolumn{2}{|c|}{$\lambda_{\max }, \mathrm{nm}$} & \multicolumn{4}{|c|}{$\mathrm{QY}^{[\mathrm{c}]}$} \\
\hline & $\operatorname{abs}^{[\mathrm{a}]}$ & fluor $^{[b]}$ & 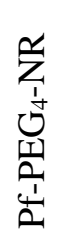 & 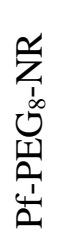 & 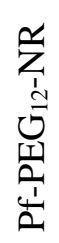 & 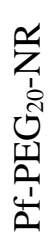 \\
\hline 1,4-Dioxane & 521 & 584 & 65 & 65 & 67 & 68 \\
\hline Acetone & 534 & 612 & 65 & 64 & 65 & 66 \\
\hline Acetonitrile & 538 & 619 & 62 & 60 & 63 & 65 \\
\hline Ethanol & 551 & 634 & 48 & 48 & 51 & 52 \\
\hline Methanol & 556 & 639 & 37 & 38 & 39 & 41 \\
\hline Water & 601 & 661 & 7 & 10 & 11 & 11 \\
\hline
\end{tabular}

[a] Position of the absorption maximum. Similar values $(+/-2 \mathrm{~nm})$ were observed for all the four conjugates. [b] Position of the emission maximum. Similar values $(+/-2$ $\mathrm{nm})$ were observed for all the four conjugates. [c] Fluorescence quantum yield. 
An important parameter for cellular studies upon wash-free conditions is the fluorescence turn-on ratio, a quantitative measure of the fluorogenic properties of the probes. Here we define it as the ratio of the fluorescence intensity at $620 \mathrm{~nm}$ in an apolar solvent (1,4-dioxane) to that in water. All the four NR conjugates demonstrated excellent fluorogenic properties with relative turn-on ratios ranging from 18to 35-fold (Figure 2B).
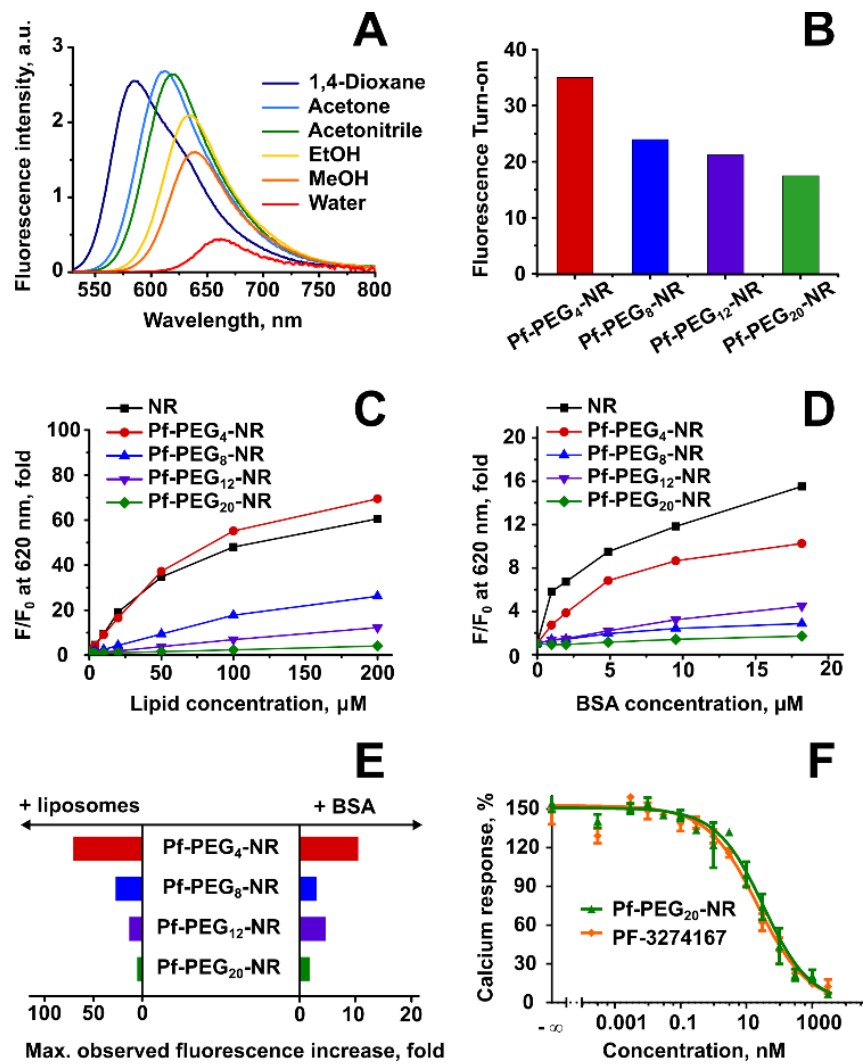

Figure 2. Fluorescence and pharmacological properties of the OTR ligands. (A) Fluorescence spectra of Pf$\mathrm{PEG}_{4}-\mathrm{NR}$ in different solvents. Fluorescence intensity is normalized to the absorbance at $520 \mathrm{~nm}$ (B) Fluorogenic properties of the OTR fluorescent ligands. The relative fluorescence turn-on was calculated as a ratio of the fluorescence intensity at $620 \mathrm{~nm}$ in 1,4-dioxane (normalized to the absorbance at $520 \mathrm{~nm}$ ) to that in water (normalized to the absorbance at $520 \mathrm{~nm}$ ). (C) Evaluation of non-specific interactions of the OTR ligands and Nile Red (NR) with DOPC/cholesterol (2:1) liposomes: fluorescence intensity increase at $620 \mathrm{~nm}$ (F/F0) as a function of liposomes concentration in PBS. (D) Evaluation of non-specific interactions of the OTR ligands and Nile Red (NR) with BSA: fluorescence intensity increase at $620 \mathrm{~nm}(\mathrm{~F} / \mathrm{F} 0)$ as a function of BSA concentration in PBS. (E) Maximal observed fluorescence increase due to non-specific interactions of the OTR ligands with liposomes and BSA. (F) Dose-response curves for OTR antagonists PF-3274167 and Pf-PEG ${ }_{20}$ NR. Data from two independent experiments performed in duplicate. Values are means \pm SEM.

Evaluation of Non-Specific Interactions. In the development of fluorescent probes for live-cell studies of membrane receptors it is crucial to carefully evaluate the non-specific interactions of the probes with cellular membranes and serum proteins. To address this issue, we used 1,2-dioleoyl-sn-glycero-3phosphocholine (DOPC) / cholesterol (2:1) large unilamellar vesicules (LUVs) as a model of cell membranes and BSA to evaluate the binding to plasma proteins. Nile Red is known for its strong nonspecific binding to lipid membranes, ${ }^{42}$ lipid droplets ${ }^{43}$ and hydrophobic protein pockets. ${ }^{44-46}$ In our 
hands, fluorescence of Nile Red (Figures $2 \mathrm{C}$ and 2D, black line) did gradually increase upon addition of liposomes or BSA to its aqueous solution. The NR conjugates were evaluated under the same conditions. As we expected based on our previous work with the OTR agonists, the increase of the length of the polar PEG spacer resulted in a gradual decrease of the non-specific interactions (Figure 2E). For instance, Pf-PEG 4 -NR bound the liposomes with similar affinity to Nile Red. Its interaction with BSA was less pronounced comparing to unmodified Nile Red but still significant, making this probe poorly compatible with the live-cells imaging conditions. Although Pf-PEG $-\mathrm{NR}$ and $\mathrm{Pf}-\mathrm{PEG}_{12}-\mathrm{NR}$ did not display significant binding to BSA, they were still strongly interacting with model membranes. Finally, the non-specific binding to lipid membranes and BSA became almost negligible for Pf- $\mathrm{PEG}_{20}-\mathrm{NR}$, making this ligand the most promising for cellular studies of the OTR.

Functional Characterization. In order to verify whether the introduction of a long $\mathrm{PEG}_{20}$ spacer influenced the functional activity of the PF-3274167 pharmacophore, we measured its effect on the calcium response in HEK 293 cells stably overexpressing the OTR (HEK-OTR cells). Both the unmodified PF-3274167 and Pf-PEG ${ }_{20}$-NR fully inhibited the oxytocin-induced calcium accumulation in a dose-dependent manner with similar $\mathrm{IC}_{50}$ of $15 \pm 3 \mathrm{nM}$ and $30 \pm 3 \mathrm{nM}$, respectively, highlighting the antagonist character of both ligands (Figure 2F). Thus, the introduction of a cumbersome $\mathrm{PEG}_{20}$ spacer capped with the aromatic fluorophore has a low impact on the functional activity of the ligand which retained its antagonist character.

Wash-Free Imaging of the OTR in Living Cells. Next, the confocal microscopy study on living HEKOTR cells was performed in order to evaluate the ability of the developed probes to detect the receptor under wash-free conditions. We were pleased to find that $\mathrm{Pf}-\mathrm{PEG}_{20}-\mathrm{NR}$, the conjugate having the most favorable combination of properties in the non-specific binding assay, showed exclusive localization on the plasma membrane. Importantly, the OTR retained on the cell membrane with no detectable ligandinduced internalization, due to the antagonist character of PF-3274167 (Figure 3). A competition assay was then used to demonstrate the specificity of the probe towards the OTR. Indeed, upon addition of a large excess of a non-fluorescent OTR-binding competitor carbetocin (CBT), the plasma membrane signal disappeared, indicating that $\mathrm{Pf}-\mathrm{PEG}_{20}-\mathrm{NR}$ binds to the cell reversibly in a receptor-specific manner. We also confirmed by confocal microscopy that the ligands with the PEG chains of 4, 8 and 12 units exhibited a strong non-specific binding, as one would have expected from the in vitro non-specific binding assay (Figure 2C-E). Their fluorescence was not influenced by the addition of the nonfluorescent competitor and, moreover, these ligands rapidly crossed the plasma membrane and stained intracellular structures. 


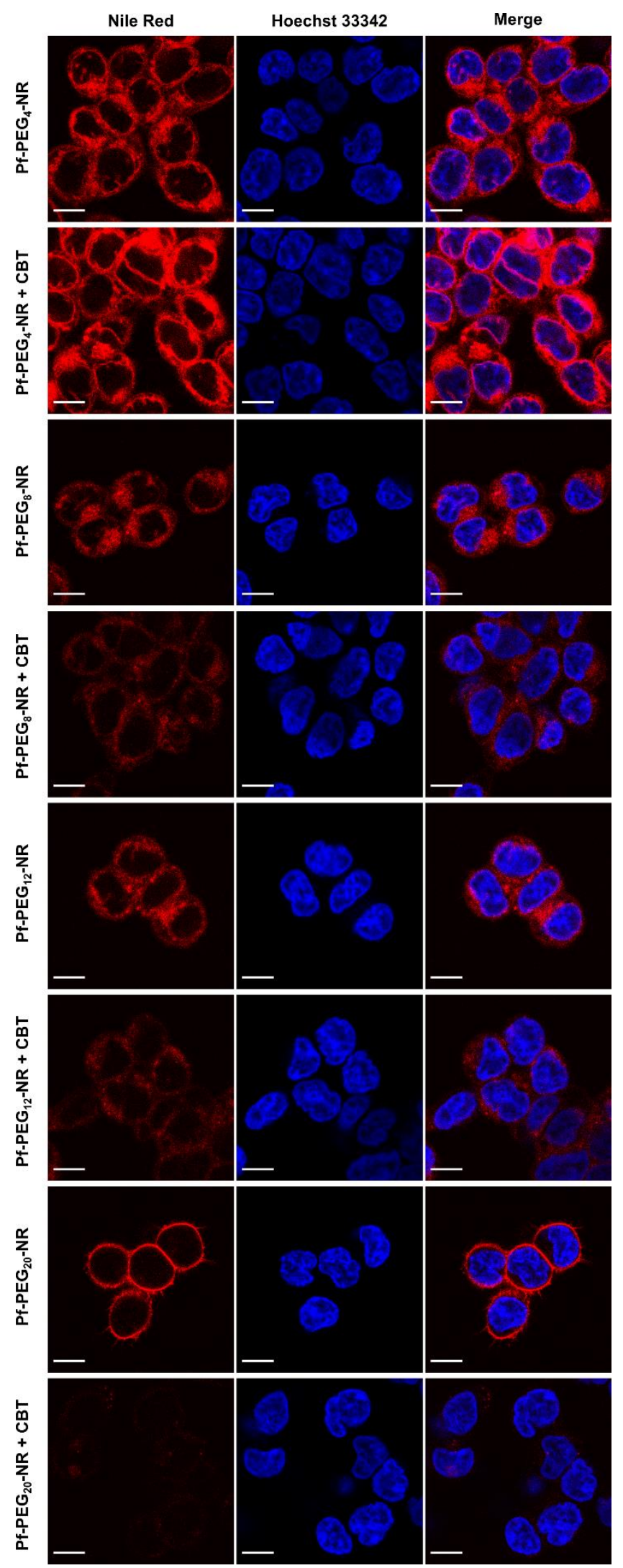

Figure 3. Confocal microscopy of the fluorogenic OTR ligands in living HEK293 cells overexpressing the OTR under no-wash conditions. Non-specific binding is evaluated in the presence of a 200 -fold excess of the nonfluorescent OTR ligand carbetocin (CBT). Concentrations: OTR ligands $10 \mathrm{nM}, \mathrm{CBT} 2 \mu \mathrm{M}$. The cells were incubated with fluorescent ligands for $20 \mathrm{~min}$ at $37^{\circ} \mathrm{C}$ prior to the imaging. Fluorescence of Nile Red $(570-$ $630 \mathrm{~nm}$ ) is shown in red, nuclei stained with Hoechst 33342 are shown in blue. Scale bars, $10 \mu \mathrm{m}$. 
Ratiometric Confocal Microscopy Studies of Local Probe Microenvironment. To demonstrate the utility of the fluorogenic NR-based ligands for selective probing of the receptor microenvironment, ratiometric confocal microscopy experiments were performed under wash-free conditions on living HEK-OTR cells. We used a ratiometry-based fluorescence sensing, which is insensitive to the concentration of the ligand and the expression level of the receptor, facilitating quantitative analysis of fluorescence data. ${ }^{19}$ Upon excitation with the $488 \mathrm{~nm}$ laser, the emitted light was collected separately in two channels, referred here as the "green" (500-600 nm) and the "red" (600-700 nm) channels. Taking into account the positive fluorescence solvatochromism of Nile Red derivatives, one could expect that a stronger fluorescence in the "red" channel indicates a more polar (or less hydrophobic) microenvironment. Accordingly, a stronger fluorescence in the "green" channel indicates less polar (or more hydrophobic) microenvironment of the fluorophore (Figure 4A). In other words, the relative "redto-green" ratio (RTG) can be used as a simple quantitative measure of the polarity of the microenvironment of the probe.

The observed RTG values differed dramatically for Pf-PEG ${ }_{20}-\mathrm{NR}$ and the other OTR ligands with shorter linker length in the cellular context (Figure 4B-E). In living cells, the fluorophore of Pf-PEG $20^{-}$ NR was surrounded by a strongly apolar microenvironment with a mean RTG value of $0.90 \pm 0.04$. For comparison, the observed mean RTG value of the membrane probe NR12 $\mathrm{S}^{30}$ (Figure 5A) localized in the outer leaflet of the plasma membrane was $0.73 \pm 0.01$. In contrast, the fluorescence of the Nile Red derivatives with shorter PEG linkers was shifted to the red with mean RTG values above 1.5. These data confirmed the conclusion drawn from the confocal microscopy images (Figure 3) about the undesired penetration of the probes with PEG lengths of 4, 8 and 12 inside the cell. It also suggested that the mentioned probes reside within intracellular membrane compartment of different composition compared to the outer leaflet of the cell membrane. The observed higher RTG values inside the cells for the probes with short PEG linkers reflect higher polarity of the intracellular membranes compared to the plasma membranes, previously reported by cell permeable solvatochromic probes. ${ }^{47}$ On the other hand, Pf$\mathrm{PEG}_{20}$-NR does not penetrate inside the cell and is localized within a rather apolar environment, likely within the lipid bilayer in the vicinity of the receptor. 

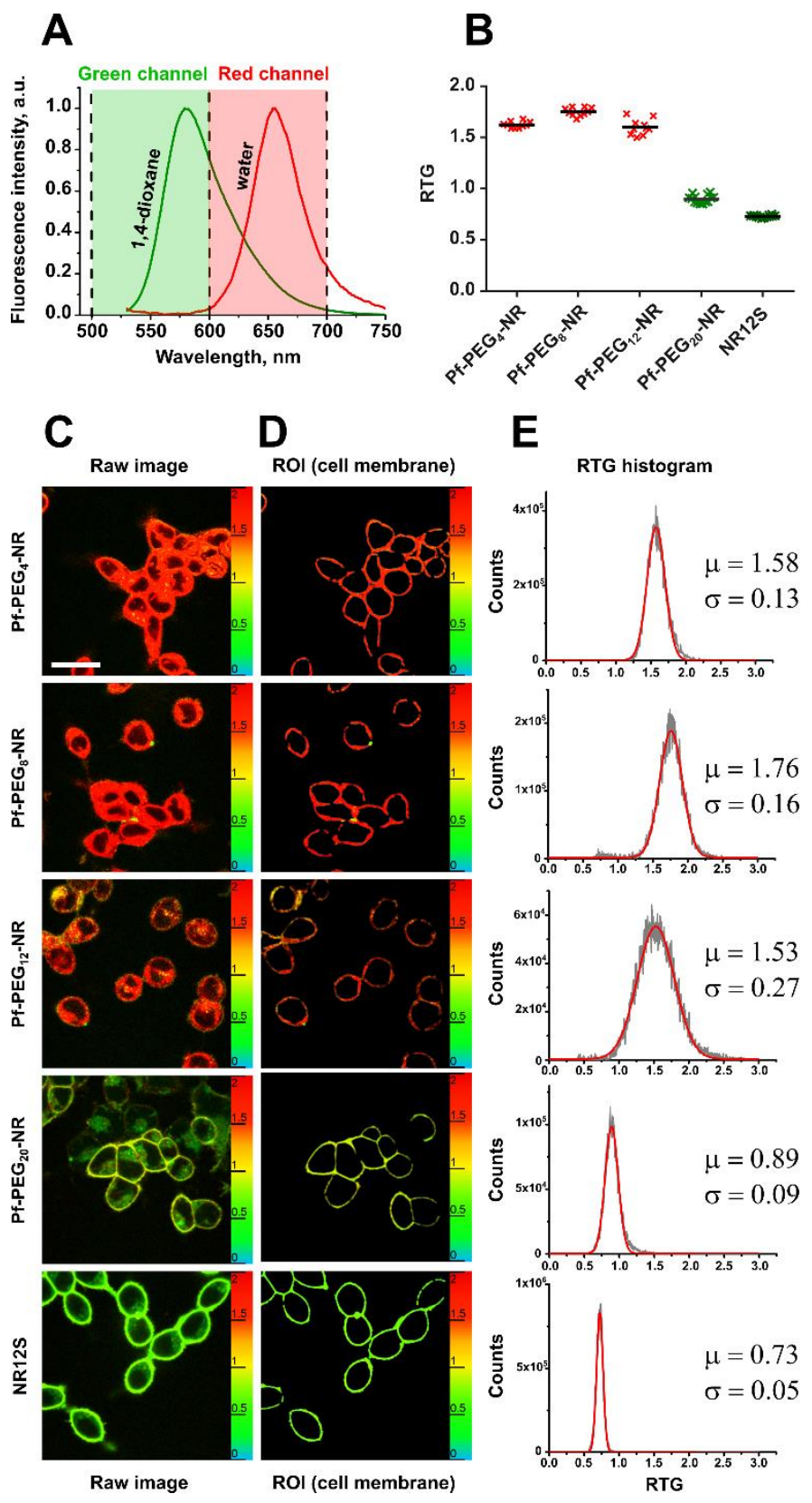

Figure 4. Ratiometric confocal microscopy imaging with NR-based probes. (A) Uncorrected normalized fluorescence spectra of Pf-PEG 4 -NR in 1,4-dioxane and water with the indication of the green and the red channels used for the calculation of the RTG ratio. (B) Comparison of mean RTG values resulted from the cellular staining for different probes. Data from two biological replicates, five to seven images per condition were analyzed. (C) Imaging of living HEK293 cells overexpressing the OTR with the NR conjugates and

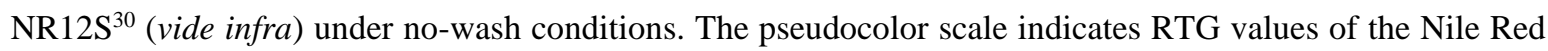
fluorescence. Scale bar, $30 \mu \mathrm{m}$. (D) ROI used for quantification. (E) Frequencies (grey) and adjusted normal distributions (red) of RTG values for the ROI presented in (D).

To further address the question of the localization of the fluorophore in Pf-PEG $\mathrm{P}_{20}-\mathrm{NR}$ bound to the OTR, we compared it with the previously reported specific peptidic OTR ligand CBT-NR ${ }^{34}$ lacking a flexible spacer between the fluorophore and the pharmacophore (Figure 5A). Although the structure of OTR bound to a peptidic ligand has not been solved yet, the recently published crystal structure of the OTR bound to a non-peptidic antagonist provides insights on the structure of the orthosteric binding pocket 
of the receptor. The study demonstrated that the OTR possesses an enlarged orthosteric binding site, situated at the extracellular part of the receptor and comprised of a polar solvent-exposed interaction surface and a hydrophobic crevice. ${ }^{48}$ In such case, it is highly unlikely that the fluorophore in CBT-NROTR complex could be deeply embedded into the cell membrane. Most probably, the fluorophore in CBT-NR bound to the OTR resides within its large ligand-binding pocket or an allosteric binding site. We obtained a mean RTG value of $1.13 \pm 0.02$ for CBT-NR bound to the OTR (Figure 5B), which indicates that the fluorophore resides within a more polar environment comparing to that of the bulk cellular membrane reported by NR12S (mean RTG value of $0.73 \pm 0.01$ ). This result is in line with the hypothesis that the fluorophore in CBT-NR is not embedded into the membrane. For the non-peptidic OTR ligand Pf-PEG ${ }_{20}-\mathrm{NR}$, its microenvironment characterized by a mean RTG value of $0.90 \pm 0.04$, was different from that of the 'linkerless' OTR ligand CBT-NR. The mean RTG value of Pf-PEG ${ }_{20}-\mathrm{NR}$ also appeared to be different from the membrane-averaged RTG value measured with the membrane probe NR12S $(0.73 \pm 0.01)$, indicating that $\mathrm{Pf}-\mathrm{PEG}_{20}-\mathrm{NR}$ could uniquely probe the local lipid bilayer surrounding the transmembrane receptor.
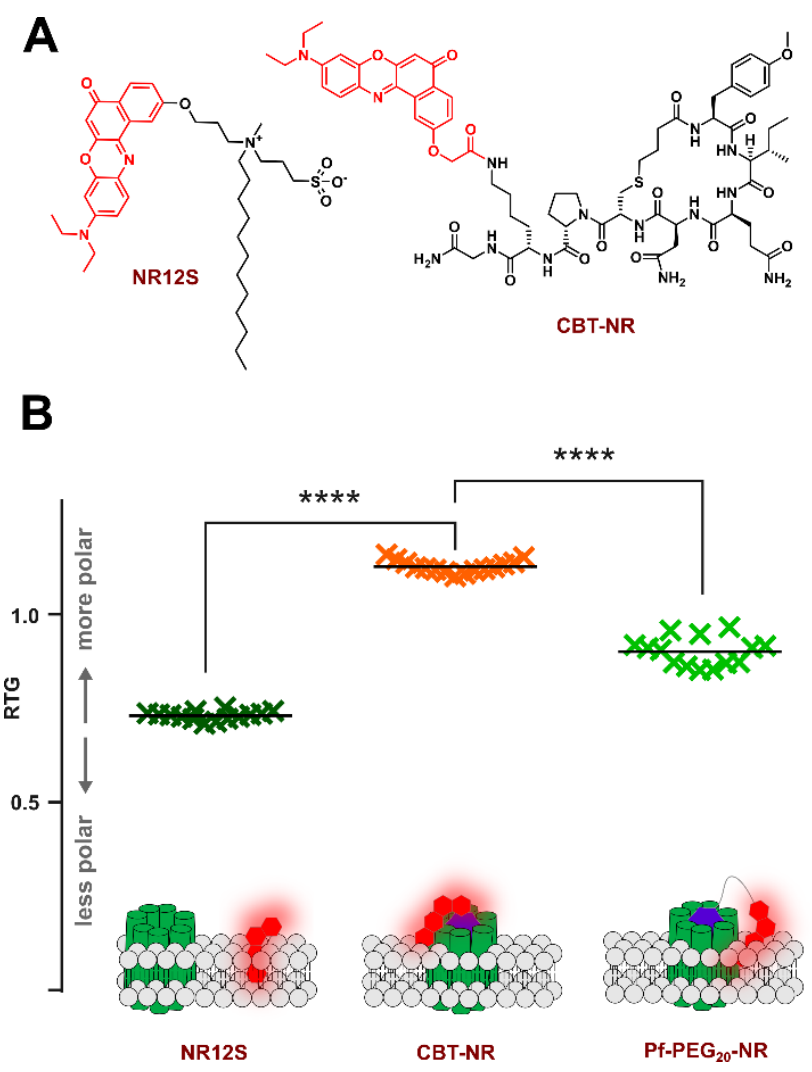

Figure 5. Evaluation of the polarity of the local microenvironment of the OTR. (A) Chemical structure of the membrane probe NR12 $\mathrm{S}^{30}$ and the peptidic OTR ligand CBT-NR ${ }^{34}$. (B) Comparison of mean RTG values resulted from the cellular staining for different probes. NR12S reports the properties of the bulk membrane, CBT-NR reports from a receptor ligand-binding pocket or an allosteric binding site, Pf-PEG20-NR reports from the lipid bilayer in the vicinity of the receptor. Data from two biological replicates, seven images per condition were analyzed. Statistics: one-way ANOVA with Tukey's multiple comparison test (confidence interval 99\%, adjusted p values: $* * * *<0.0001)$. 
If the suggestion that Pf- $\mathrm{PEG}_{20}-\mathrm{NR}$ resided in the lipid bilayer in the vicinity of the receptor was correct, the probe should report changes in the lipid composition of the cell membrane. Klymchenko et al. ${ }^{30}$ showed that the membrane probe NR12S displayed a red shift of fluorescence spectrum upon treatment of living U87MG cells with methyl- $\beta$-cyclodextrin $(\mathrm{M} \beta C D)$. One of the known effects of M $\beta C D$ treatment is cholesterol depletion, which would decrease the number and size of the cholesterol-rich ordered $\left(\mathrm{L}_{0}\right)$ microdomains in the plasma membrane. ${ }^{49}$ We performed M $\beta C D$ treatment in our cell line (HEK293) stably overexpressing the OTR in presence of the NR-based probes. The emission of NR12S shifted slightly to the red upon $\mathrm{M} \beta C D$ treatment as follows from the increase of its mean RTG value from $0.73 \pm 0.01$ to $0.79 \pm 0.02$ (Figure 6). Under the same condition, the receptor-bound probe Pf$\mathrm{PEG}_{20}$-NR displayed a similar trend by increasing its mean RTG value from $0.90 \pm 0.04$ to $0.98 \pm 0.08$. The unidirectional shift of the mean RTG for the both probes supports out suggestion that the fluorophore of the Pf-PEG ${ }_{20}$-NR probe reaches the membrane and reports the changes of local lipid environment of the receptor.

A

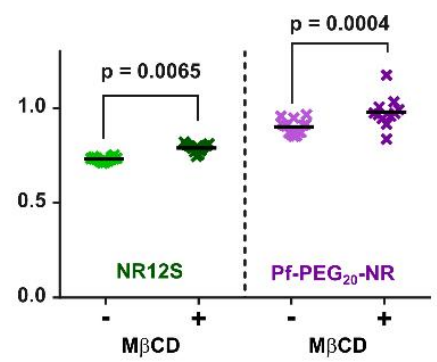

\section{B}

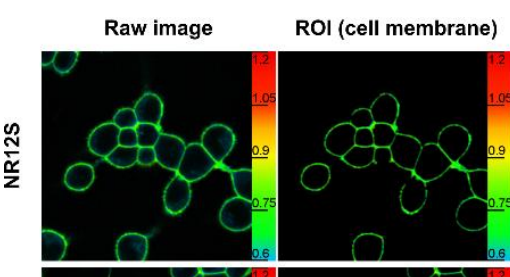

D

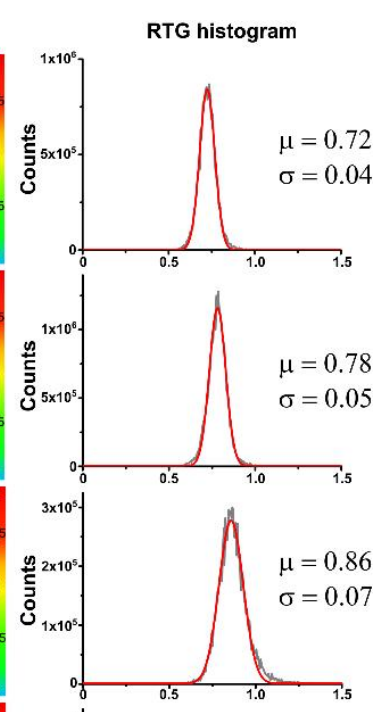

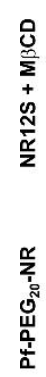

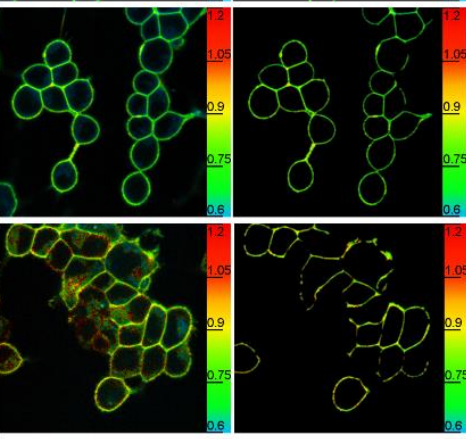

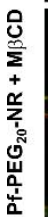
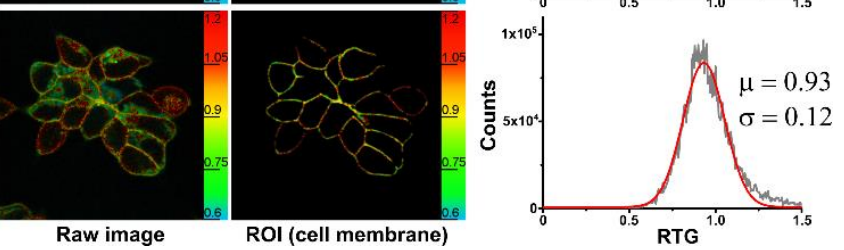

Figure 6. Influence of the $M \beta C D$ treatment on the local microenvironment of the OTR. (A) Comparison of mean RTG values resulted from the cellular staining with Pf-PEG $\mathrm{P}_{20}-\mathrm{NR}$ and NR12S before and after the M $\beta C D$ treatment. Data from two biological replicates, seven images per condition were analyzed. Statistics: one-way ANOVA with Tukey's multiple comparison test (confidence interval 99\%). (B) Imaging of living HEK293 
cells overexpressing the OTR stained Pf-PEG $20-\mathrm{NR}$ and NR12S under no-wash conditions before and after the $\mathrm{M} \beta C D$ treatment. The pseudocolor scale indicates RTG values of the Nile Red fluorescence. Scale bar, $30 \mu \mathrm{m}$. (C) ROI used for quantification. (D) Frequencies (grey) and adjusted normal distributions (red) of RTG values for the ROI presented in $(\mathrm{C})$.

\section{Conclusions}

In this work, we developed first environment-sensitive antagonist probes for the oxytocin GPCR by covalently tethering the Nile Red fluorophore to a non-peptidic OTR antagonist. Our best probe Pf$\mathrm{PEG}_{20}$-NR featured a combination of excellent fluorogenicity, strong positive solvatochromism and negligible non-specific binding to lipid membranes and serum proteins. It enabled fluorescence imaging of the OTR in cultured cells under wash-free conditions with negligible background fluorescence. The new conjugate also enabled direct fluorescence ratiometric probing of the local plasma membrane microenvironment in the proximity to the transmembrane receptor. To date, very few methods are available for studying lipid heterogeneity of the cell membrane in space and time. None of these methods has been used for the analysis of lipid bilayer in the vicinity of an unmodified $G$ protein-coupled receptor. In this context, $\mathrm{Pf}-\mathrm{PEG}_{20}-\mathrm{NR}$ represents the first fluorescent GPCR ligand able to probe the microenvironment of the unmodified receptor. The probe design presented in this work could be easily expanded for studies of other membrane receptors.

\section{Experimental Section}

\section{Materials and Methods}

Reagents were obtained from commercial sources and used without any further purification. Compounds $\mathbf{5}, \mathbf{6 a}, \mathbf{6 b}, 7 \mathbf{a}, 7 \mathbf{b}, 8 \mathbf{a}$ and $8 \mathrm{~b}$ were synthesized following the previously published protocols. ${ }^{38}$ Compound 6c was synthesized according to Zhang, et al. ${ }^{50}$ Thin-layer chromatography was performed on Merck silica gel 60F254 plates. VWR silica gel $(40-63 \mu \mathrm{m})$ was used for chromatography columns. Semipreparative reverse-phase HPLC purifications were performed on a Waters SunFire C18 OBD Prep column $(5 \mu \mathrm{m}, 19 \times 150 \mathrm{~mm})$ on a Gilson PLC2020 system. Reverse-phase flash purifications were performed on prepacked Puriflash C18 columns from Interchim on a Gilson PLC2020 system. Analytical reverse-phase HPLC were performed on an Ascentis Express C18 column $(2.7 \mu \mathrm{m}, 4.6 \mathrm{~mm}$ $\times 75 \mathrm{~mm}$ ) on an Agilent Technologies 1200 series HPLC system using a linear gradient (5\% to 100\% $\mathrm{v} / \mathrm{v}$ in $7.3 \mathrm{~min}$, flow rate of $\left.1.6 \mathrm{~mL} \cdot \mathrm{min}^{-1}\right)$ of solvent B $(0.1 \% \mathrm{v} / \mathrm{v}$ TFA in ACN) in solvent $\mathrm{A}(0.1 \% \mathrm{v} / \mathrm{v}$ TFA in $\mathrm{H}_{2} \mathrm{O}$ ). ${ }^{1} \mathrm{H}$ NMR spectra were recorded at $400 \mathrm{MHz}$ and $500 \mathrm{MHz}$ and ${ }^{13} \mathrm{C}$ NMR spectra were recorded at $101 \mathrm{MHz}$ and $126 \mathrm{MHz}$, on a Bruker Advance spectrometer. Chemical shifts are reported in parts per million $(\mathrm{ppm})$, coupling constants $(\mathrm{J})$ are reported in hertz $(\mathrm{Hz})$. Signals are described as $\mathrm{s}$ (singlet), d (doublet), $\mathrm{t}$ (triplet), q (quadruplet), $\mathrm{p}$ (pentuplet) and $\mathrm{m}$ (multiplet). Low resolution mass spectra (LRMS) and high resolution mass spectra (HRMS) were obtained on an Agilent Technologie 6520 Accurare-Mass Q.Tof LC/MS apparatus equipped with a Zorbax SB $\mathrm{C}_{18}$ column $(1.8 \mu \mathrm{m}, 2.1 \times 50$ $\mathrm{mm}$ ) using electrospray ionization (ESI) and a time-of-flight analyzer (TOF). Absorption and fluorescence measurement were performed in 114F-QS $10 \mathrm{~mm}$ quartz fluorescence cuvettes (Hellma Analytics). Absorption spectra were recorded on a Cary 4000-HP spectrophotometer (Varian) and fluorescence spectra on a FluoroMax 4 (Jobin Yvon, Horiba) spectrofluorometer equipped with a 
thermostated cuvette holder at $20{ }^{\circ} \mathrm{C}$. The solvents used were either of spectroscopy or HPLC grade. Fluorescence confocal microscopy experiments were performed on a Leica TCS SPE-II microscope with an HXC PL APO 63x/1.40 OIL CS objective.

\section{Synthesis}

5-(diethylamino)-2-nitrosophenol (2). To a solution of $\mathbf{1}(1.00 \mathrm{~g}, 5.87 \mathrm{mmol}, 1 \mathrm{eq}$.) in a mixture of water $(6 \mathrm{~mL})$ and concentrated $\mathrm{HCl}(6 \mathrm{~mL}, 70.5 \mathrm{mmol}, 12$ eq. $)$ at iced water temperature was dropwise added a solution of $\mathrm{NaNO}_{2}(418 \mathrm{mg}, 5.87 \mathrm{mmol}, 1$ eq.) in water $(4 \mathrm{~mL})$ over a period of $30 \mathrm{~min}$. The mixture was stirred at iced water temperature for $2 \mathrm{~h}$ and then concentrated under vacuum to afford a brown solid (1.14 g). This unstable product was directly used for the next step. HPLC $t_{R}=2.22 \min$ (> 95\% purity [220.8 nm]). ${ }^{1} \mathrm{H} \mathrm{NMR}\left(400 \mathrm{MHz}, \mathrm{CDCl}_{3}\right) \delta 7.31(\mathrm{~d}, J=9.9 \mathrm{~Hz}, 1 \mathrm{H}), 6.53(\mathrm{dd}, J=9.9,2.5$ $\mathrm{Hz}, 1 \mathrm{H}), 5.66(\mathrm{~d}, J=2.6 \mathrm{~Hz}, 1 \mathrm{H}), 3.48(\mathrm{q}, J=7.0 \mathrm{~Hz}, 4 \mathrm{H}), 1.26(\mathrm{t}, J=7.2 \mathrm{~Hz}, 6 \mathrm{H}) .{ }^{13} \mathrm{C}$ NMR $(101$ $\left.\mathrm{MHz}, \mathrm{CDCl}_{3}\right) \delta 169.36,157.23,149.68,135.57,113.69,96.12,46.07,13.00$.

9-(diethylamino)-2-hydroxy-5H-benzo[a]phenoxazin-5-one (3). A solution of naphthalene-1,6-diol (73.0 mg, $0.45 \mathrm{mmol}, 1$ eq.) in anhydrous DMF (4 mL) was added to a solution of 2 (175 mg, 0.90 mmol, 2 eq.) in anhydrous DMF $(1 \mathrm{~mL})$. The mixture was stirred at $110{ }^{\circ} \mathrm{C}$ for $45 \mathrm{~min}$. DMF was removed under reduced pressure and the crude product was purified by reverse-phase flash chromatography using a linear gradient of $15-70 \%$ ACN (0.1\% TFA) in $\mathrm{H}_{2} \mathrm{O}(0.1 \%$ TFA) in 30 min to afford after lyophilization a dark purple solid $(66.5 \mathrm{mg}, 44 \%)$. HPLC $\mathrm{t}_{\mathrm{R}}=4.57 \mathrm{~min}(>95 \%$ purity $[220.8$ $\mathrm{nm}]) .{ }^{1} \mathrm{H}$ NMR $\left(500 \mathrm{MHz}, \mathrm{DMSO}-d_{6}\right) \delta 10.40(\mathrm{~s}, 1 \mathrm{H}), 7.96(\mathrm{~d}, J=8.6 \mathrm{~Hz}, 1 \mathrm{H}), 7.87(\mathrm{~d}, J=2.5 \mathrm{~Hz}, 1 \mathrm{H})$, $7.56(\mathrm{~d}, J=9.0 \mathrm{~Hz}, 1 \mathrm{H}), 7.08(\mathrm{dd}, J=8.6,2.5 \mathrm{~Hz}, 1 \mathrm{H}), 6.78(\mathrm{dd}, J=9.1,2.7 \mathrm{~Hz}, 1 \mathrm{H}), 6.62(\mathrm{~d}, J=2.7$ $\mathrm{Hz}, 1 \mathrm{H}), 6.14(\mathrm{~s}, 1 \mathrm{H}), 3.48(\mathrm{q}, J=7.1 \mathrm{~Hz}, 4 \mathrm{H}), 1.15$ (t, $J=7.0 \mathrm{~Hz}, 6 \mathrm{H}) .{ }^{13} \mathrm{C}$ NMR (126 MHz, DMSO) $\delta 181.37,159.78,151.56,150.71,144.95,138.59,134.87,132.01,128.40,125.16,123.11,118.34$, $110.01,107.47,105.80,95.33,45.28,12.98$.

2-((9-(diethylamino)-5-oxo-5H-benzo[a]phenoxazin-2-yl)oxy)acetic acid (4). To a solution of 3 (537 $\mathrm{mg}, 1.60 \mathrm{mmol}, 1$ eq.) and $\mathrm{K}_{2} \mathrm{CO}_{3}(1.32 \mathrm{~g}, 9.58 \mathrm{mmol}, 6 \mathrm{eq}$.) in acetone $(16 \mathrm{~mL})$ was added tert-butyl chloroacetate $(0.7 \mathrm{~mL}, 4.79 \mathrm{mmol}, 3$ eq. $)$. The mixture was stirred under reflux for $6.5 \mathrm{~h}$. The solvent was evaporated under reduced pressure and the residue was dissolved in ethyl acetate $(50 \mathrm{~mL})$, washed with water and brine, dried over anhydrous $\mathrm{Na}_{2} \mathrm{SO}_{4}$ and concentrated under reduced pressure. The obtained residue was dissolved in DCM $(9 \mathrm{~mL})$ and TFA $(6 \mathrm{~mL})$ was added. The mixture was stirred at $25{ }^{\circ} \mathrm{C}$ for $1.5 \mathrm{~h}$. After evaporation of the volatiles under reduced pressure, ethyl acetate $(50 \mathrm{~mL})$ was added and the organic layer was washed with water and brine, dried over anhydrous $\mathrm{Na}_{2} \mathrm{SO}_{4}$ and concentrated under reduced pressure. The crude product was purified by reverse-phase flash chromatography using a linear gradient of $30-80 \%$ ACN $\left(0.1 \%\right.$ TFA) in $\mathrm{H}_{2} \mathrm{O}(0.1 \%$ TFA) in 30 min to afford after lyophilization a dark purple solid $(721 \mathrm{mg}, 84 \%)$. HPLC $t_{R}=4.57 \mathrm{~min}(>95 \%$ purity [220.8 $\mathrm{nm}]) .{ }^{1} \mathrm{H}$ NMR (DMSO- $\left.d_{6}\right) \delta 8.01(\mathrm{~d}, J=8.7,1 \mathrm{H}), 7.84(\mathrm{~d}, J=2.7 \mathrm{~Hz}, 1 \mathrm{H}), 7.53(\mathrm{~d}, J=9.1 \mathrm{~Hz}, 1 \mathrm{H})$, $7.24(\mathrm{dd}, J=8.7,2.7 \mathrm{~Hz}, 1 \mathrm{H}), 6.79-6.72(\mathrm{~m}, 1 \mathrm{H}), 6.57(\mathrm{~d}, J=2.6 \mathrm{~Hz}, 1 \mathrm{H}), 6.14(\mathrm{~s}, 1 \mathrm{H}), 4.87(\mathrm{~s}, 2 \mathrm{H})$, $3.46(\mathrm{~m}, 4 \mathrm{H}), 1.15(\mathrm{t}, J=7.0 \mathrm{~Hz}, 6 \mathrm{H}) .{ }^{13} \mathrm{C}$ NMR (DMSO) $\delta 181.12,169.74,160.26,151.68,150.86$, 146.42 , 137.97, 133.40, 130.91, 127.19, 125.23, 124.00, 117.80, 110.14, 106.51, 103.98, 95.94, 64.74, $44.43,12.43$.

59-azido-3,6,9,12,15,18,21,24,27,30,33,36,39,42,45,48,51,54,57-nonadecaoxanonapentacontyl 4methylbenzenesulfonate (6d). To a solution of N3-PEG(20)-OH (50.0 mg, $54.1 \mu \mathrm{mol}$, 1 eq.) in anhydrous DCM (1 mL) were added 4-methylbenzenesulfonyl chloride (21 mg, $108 \mu \mathrm{mol}, 2 \mathrm{eq}$.$) and$ 
$\mathrm{KOH}(18.2 \mathrm{mg}, 325 \mu \mathrm{mol}, 6 \mathrm{eq}$.). The mixture was stirred at iced water temperature for $1 \mathrm{~h}$ then at room temperature for 3 days. DCM $(50 \mathrm{~mL})$ was added and the organic layer was washed with water, brine, dried over anhydrous $\mathrm{Na}_{2} \mathrm{SO}_{4}$ and concentrated under reduced pressure. The crude product was purified by flash chromatography eluted with 5-10\% v/v MeOH in DCM to afford a colorless oil (47.2 $\mathrm{mg}, 81 \%)$. HPLC $\mathrm{t}_{\mathrm{R}}=4.59 \mathrm{~min}(>95 \%$ purity $[220.8 \mathrm{~nm}]) .{ }^{1} \mathrm{H} \mathrm{NMR}\left(400 \mathrm{MHz}, \mathrm{CDCl}_{3}\right) \delta 7.75(\mathrm{~d}, J=7.0 \mathrm{~Hz}, 2 \mathrm{H})$, $7.30(\mathrm{~d}, J=7.9 \mathrm{~Hz}, 2 \mathrm{H}), 4.11(\mathrm{t}, J=4.4 \mathrm{~Hz}, 2 \mathrm{H}), 3.67-3.52(\mathrm{~m}, 76 \mathrm{H}), 3.34(\mathrm{t}, J=5.1 \mathrm{~Hz}, 2 \mathrm{H}), 2.41(\mathrm{~s}$, $3 \mathrm{H}) .{ }^{13} \mathrm{C} \mathrm{NMR}\left(101 \mathrm{MHz}, \mathrm{CDCl}_{3}\right) \delta 144.79,133.15,129.85,128.00,70.77,70.73,70.70,70.67,70.60$, $70.55,70.05,69.27,68.71,50.74,21.65$.

\section{5-(3-(37-azido-2,5,8,11,14,17,20,23,26,29,32,35-dodecaoxahepta triacontyl)-5-(3-(2-chloro-4-} fluorophenoxy)azetidin-1-yl)-4H-1,2,4-triazol-4-yl)-2-methoxypyridine (7c). To a solution of 5 (19.5 mg, $47.9 \mu \mathrm{mol}, 1$ eq.) in anhydrous DMF ( $3 \mathrm{~mL}$ ) at iced water temperature was added $\mathrm{KOH}$ (19 $\mathrm{mg}, 302 \mu \mathrm{mol}, 6.3$ eq.). The solution was stirred for $5 \mathrm{~min}$ before a solution of $\mathbf{6 c}$ ( $34.8 \mathrm{mg}, 47.9 \mu \mathrm{mol}$, 1 eq.) in anhydrous DMF ( $3 \mathrm{~mL}$ ) was added. The mixture was stirred at iced water temperature for 1.5 $\mathrm{h}$ and at $25{ }^{\circ} \mathrm{C}$ for $1 \mathrm{~h}$. DMF was evaporated, to the residue DCM $(70 \mathrm{~mL})$ was added and the organic layer was washed with water, brine, dried over anhydrous $\mathrm{Na}_{2} \mathrm{SO}_{4}$, concentrated under vacuum and lyophilized to afford a yellow oil $(42,5 \mathrm{mg}, 92 \%)$. HPLC $t_{\mathrm{R}}=4.56 \mathrm{~min}(>95 \%$ purity $[220.8 \mathrm{~nm}]) .{ }^{1} \mathrm{H}$ NMR $\left(400 \mathrm{MHz}, \mathrm{CDCl}_{3}\right) \delta 8.22(\mathrm{~d}, J=2.7 \mathrm{~Hz}, 1 \mathrm{H}), 7.67(\mathrm{dd}, J=8.9,2.7 \mathrm{~Hz}, 1 \mathrm{H}), 7.13(\mathrm{dd}, J=8.0$, $3.0 \mathrm{~Hz}, 1 \mathrm{H}), 6.86(\mathrm{~d}, J=8.7 \mathrm{~Hz}, 2 \mathrm{H}), 6.51(\mathrm{dd}, J=9.0,4.7 \mathrm{~Hz}, 1 \mathrm{H}), 4.90(\mathrm{p}, J=5.7 \mathrm{~Hz}, 1 \mathrm{H}), 4.42(\mathrm{~s}$, $2 \mathrm{H}), 4.18-4.10(\mathrm{~m}, 2 \mathrm{H}), 4.05-4.00(\mathrm{~m}, 2 \mathrm{H}), 3.99(\mathrm{~s}, 3 \mathrm{H}), 3.70-3.53(\mathrm{~m}, 46 \mathrm{H}), 3.38(\mathrm{t}, J=5.0 \mathrm{~Hz}$, 2H). ${ }^{13} \mathrm{C}$ NMR $\left(101 \mathrm{MHz}, \mathrm{CDCl}_{3}\right) \delta 164.42,158.34,149.74,148.88,145.56,137.74,123.58,118.26$, $118.00,114.31,114.09,111.78,70.72,70.70,70.66,70.59,70.52,70.27,70.05,69.30,68.86,62,45$, $59.46,54.09,50.74$.

5-(3-(3-(( $\left(\lambda^{1}\right.$-oxidaneyl)methyl)-59-azido-2,6,9,12,15,18,21,24,27, $\quad 30,33,36,39,42,45,48,51,54,57-$ nonadecaoxanonapentacontyl)-5-(3-(2-chloro-4-fluorophenoxy)azetidin-1-yl)-4H-1,2,4-triazol-4yl)-2-methoxypyridine (7d). To a solution of $\mathbf{5}(10.0 \mathrm{mg}, 24.6 \mu \mathrm{mol}, 1$ eq.) in anhydrous DMF (1.7 $\mathrm{mL})$ at iced water temperature was added $\mathrm{KOH}(19 \mathrm{mg}, 295 \mu \mathrm{mol}, 14 \mathrm{eq}$.). The solution was stirred for $10 \mathrm{~min}$ before a solution of $\mathbf{6 d}(26.6 \mathrm{mg}, 24.6 \mu \mathrm{mol}, 1$ eq. $)$ in anhydrous DMF $(1.6 \mathrm{~mL})$ was added. The mixture was stirred at iced water temperature for $30 \mathrm{~min}$ and at $25{ }^{\circ} \mathrm{C}$ for $2.5 \mathrm{~h}$. DCM (70 mL) was added and the organic layer was washed with water, brine, dried over anhydrous $\mathrm{Na}_{2} \mathrm{SO}_{4}$ and concentrated under reduced pressure. The crude product was purified by semi-preparative HPLC using a linear gradient of $20-50 \%$ ACN $\left(0.1 \% \mathrm{v} / \mathrm{v}\right.$ TFA) in $\mathrm{H}_{2} \mathrm{O}(0.1 \% \mathrm{v} / \mathrm{v}$ TFA) in 30 min to afford after lyophilization a colorless oil $(23.2 \mathrm{mg}, 72 \%)$. $\mathrm{HPLC}_{\mathrm{R}}=4.67 \mathrm{~min}\left(>95 \%\right.$ purity [220.8 nm]). ${ }^{1} \mathrm{H}$ NMR $\left(400 \mathrm{MHz}, \mathrm{CDCl}_{3}\right) \delta 8.32(\mathrm{~s}, 1 \mathrm{H}), 7.81(\mathrm{~d}, J=8.7 \mathrm{~Hz}, 1 \mathrm{H}), 7.12(\mathrm{dd}, J=7.9,2.7 \mathrm{~Hz}, 1 \mathrm{H}), 6.95-6.85$ $(\mathrm{m}, 2 \mathrm{H}), 6.55(\mathrm{dd}, J=9.2,4.6 \mathrm{~Hz}, 1 \mathrm{H}), 4.99(\mathrm{~s}, 1 \mathrm{H}), 4.49(\mathrm{~s}, 2 \mathrm{H}), 4.40(\mathrm{~s}, 2 \mathrm{H}), 4.13(\mathrm{~d}, J=7.4 \mathrm{~Hz}, 2 \mathrm{H})$, $4.01(\mathrm{~s}, 3 \mathrm{H}), 3.64(\mathrm{~s}, 78 \mathrm{H}), 3.38(\mathrm{t}, J=5.0 \mathrm{~Hz}, 2 \mathrm{H})$. LRMS (ESI) calcd for $\mathrm{C}_{58} \mathrm{H}_{98} \mathrm{ClFN}_{8} \mathrm{O}_{22}[\mathrm{M}+2 \mathrm{H}]^{2+} / 2$ : 656.323, found: 656.283 .

\section{3-(( $\lambda^{1}$-oxidaneyl)methyl)-1-(5-(3-(2-chloro-4-fluorophenoxy)azetidin-1-yl)-4-(6-methoxypyridin-} 3-yl)-4H-1,2,4-triazol-3-yl)-2,6,9,12,15,18,21, 24,27,30,33-undecaoxapentatriacontan-35-aminium 2,2,2-trifluoroacetate (8c). Polymer-bound triphenylphosphine $(70.8 \mathrm{mg}, 3 \mathrm{mmol} / \mathrm{g}, 8$ eq.) was added to a solution of $7 \mathbf{c}(25.5 \mathrm{mg}, 26.6 \mu \mathrm{mol}, 1$ eq.) in anhydrous THF $(1 \mathrm{~mL})$. The mixture was stirred under reflux for $3.5 \mathrm{~h}$, then water $(400 \mu \mathrm{L})$ was added and the obtained mixture was stirred under reflux for another $1.5 \mathrm{~h}$. The mixture was filtered and the filtrate was concentrated under reduced pressure and lyophilized. The crude product was purified by semi-preparative HPLC using a linear gradient of 20$45 \% \operatorname{ACN}\left(0.1 \%\right.$ v/v TFA) in $\mathrm{H}_{2} \mathrm{O}(0.1 \% \mathrm{v} / \mathrm{v}$ TFA $)$ in $30 \mathrm{~min}$ to afford after lyophilization a yellow oil 
(11.9 mg, 43\%). HPLC $\mathrm{t}_{\mathrm{R}}=3.94 \mathrm{~min}\left(>95 \%\right.$ purity [280.8 nm]). ${ }^{1} \mathrm{H}$ NMR $\left(400 \mathrm{MHz}, \mathrm{CDCl}_{3}\right) \delta 8.27$ $(\mathrm{d}, J=2.7 \mathrm{~Hz}, 1 \mathrm{H}), 7.77(\mathrm{dd}, J=8.9,2.7 \mathrm{~Hz}, 1 \mathrm{H}), 7.68(\mathrm{~s}, 2 \mathrm{H}), 7.12(\mathrm{dd}, J=8.0,3.1 \mathrm{~Hz}, 1 \mathrm{H}), 6.90(\mathrm{~d}$, $J=8.7 \mathrm{~Hz}, 2 \mathrm{H}), 6.53(\mathrm{dd}, J=9.1,4.7 \mathrm{~Hz}, 1 \mathrm{H}), 5.02-4.89(\mathrm{~m}, 1 \mathrm{H}), 4.43(\mathrm{~s}, 2 \mathrm{H}), 4.39-4.31(\mathrm{~m}, 2 \mathrm{H})$, $4.08(\mathrm{dd}, J=8.7,3.6 \mathrm{~Hz}, 2 \mathrm{H}), 4.00(\mathrm{~s}, 3 \mathrm{H}), 3.80(\mathrm{t}, J=4.9 \mathrm{~Hz}, 2 \mathrm{H}), 3.71-3.56(\mathrm{~m}, 44 \mathrm{H}), 3.23-3.12$ $(\mathrm{m}, 2 \mathrm{H})$.

\section{3-(( $\lambda^{1}$-oxidaneyl)methyl)-1-(5-(3-(2-chloro-4-fluorophenoxy)azetidin-1-yl)-4-(6-methoxypyridin-} 3-yl)-4H-1,2,4-triazol-3-yl)-2,6,9,12,15,18,21, 24,27,30,33,36,39,42,45,48,51,54,57nonadecaoxanonapentacontan-59-aminium 2,2,2-trifluoroacetate $\quad(\mathbf{8 d}) . \quad$ Polymer-bound triphenylphosphine ( $33.8 \mathrm{mg}, 3 \mathrm{mmol} / \mathrm{g}, 10$ eq.) was added to a solution of $7 \mathbf{d}$ ( $13.3 \mathrm{mg}, 10.1 \mu \mathrm{mol}, 1$ eq.) in anhydrous THF $(500 \mu \mathrm{L})$. The mixture was refluxed for $5 \mathrm{~h}$, then water $(200 \mu \mathrm{L})$ was added and the obtained mixture was stirred under reflux for another $2 \mathrm{~h}$. The mixture was filtered and the filtrate was concentrated under reduced pressure and lyophilized. The crude product was purified by semipreparative HPLC using a linear gradient of $20-45 \%$ ACN $\left(0.1 \%\right.$ v/v TFA) in $\mathrm{H}_{2} \mathrm{O}(0.1 \% \mathrm{v} / \mathrm{v}$ TFA) in $30 \mathrm{~min}$ to afford after lyophilization a colorless oil $(5.8 \mathrm{mg}, 44 \%)$. HPLC $\mathrm{t}_{\mathrm{R}}=4.32 \mathrm{~min}(>95 \%$ purity [220.8 nm]). ${ }^{1} \mathrm{H}$ NMR $\left(400 \mathrm{MHz}, \mathrm{CDCl}_{3}\right) \delta 8.20(\mathrm{~d}, J=2.7 \mathrm{~Hz}, 1 \mathrm{H}), 7.65(\mathrm{dd}, J=8.8,2.7 \mathrm{~Hz}, 1 \mathrm{H}), 7.10$ $(\mathrm{dd}, J=8.0,3.0 \mathrm{~Hz}, 1 \mathrm{H}), 6.89-6.77(\mathrm{~m}, 2 \mathrm{H}), 6.49(\mathrm{dd}, J=9.0,4.7 \mathrm{~Hz}, 1 \mathrm{H}), 4.88(\mathrm{p}, J=6.2,5.6 \mathrm{~Hz}$, $1 \mathrm{H}), 4.39$ (s, 2H), $4.17-4.05(\mathrm{~m}, 2 \mathrm{H}), 4.04-3.97(\mathrm{~m}, 2 \mathrm{H}), 3.97$ (s, 3H), $3.66-3.58(\mathrm{~m}, 78 \mathrm{H}), 2.99$ (t, $J=5.0 \mathrm{~Hz}, 2 \mathrm{H})$. LRMS (ESI) calcd for $\mathrm{C}_{58} \mathrm{H}_{100} \mathrm{ClFN}_{6} \mathrm{O}_{22}[\mathrm{M}+2 \mathrm{H}]^{2+} / 2: 643.328$, found: 643.764 .

Pf-PEG 4 -NR. To a solution of 4 (3.6 mg, $9.17 \mu \mathrm{mol}, 1$ eq.) in anhydrous DMF (300 $\mu \mathrm{L})$ were added a solution of 8a (7.0 mg, $10.1 \mu \mathrm{mol}, 1.1$ eq.) in anhydrous DMF (300 $\mu \mathrm{L})$, a solution of PYBOP (13.6 $\mathrm{mg}, 26.3 \mu \mathrm{mol}, 2.6$ eq.) in anhydrous DMF $(300 \mu \mathrm{L})$ and DIPEA $(13.3 \mu \mathrm{L}, 80.6 \mu \mathrm{mol}, 8$ eq.). The mixture was stirred at $25^{\circ} \mathrm{C}$ for $1 \mathrm{~h}$ and the product was then isolated by semi-preparative HPLC using a linear gradient of $20-60 \%$ ACN $\left(0.1 \% \mathrm{v} / \mathrm{v}\right.$ TFA) in $\mathrm{H}_{2} \mathrm{O}(0.1 \% \mathrm{v} / \mathrm{v}$ TFA $)$ in $30 \mathrm{~min}$ to afford after lyophilization a dark purple solid $(6.8 \mathrm{mg}, 78 \%)$. HPLC $\mathrm{t}_{\mathrm{R}}=5.37 \mathrm{~min}(>95 \%$ purity $[220.8 \mathrm{~nm}])$. HRMS (ESI) calcd for $\mathrm{C}_{48} \mathrm{H}_{54} \mathrm{ClFN}_{8} \mathrm{O}_{10}[\mathrm{M}+2 \mathrm{H}]^{2+} / 2: 478.1818$; found: 478.1824 .

Pf-PEG ${ }_{8}$-NR. To a solution of 4 ( $0.63 \mathrm{mg}, 1.61 \mu \mathrm{mol}, 1$ eq.) in anhydrous DMF (65 $\left.\mu \mathrm{L}\right)$ were added a solution of $\mathbf{8 b}$ (1.40 mg, $1.61 \mu \mathrm{mol}, 1$ eq.) in anhydrous DMF $(65 \mu \mathrm{L})$, a solution of PYBOP (2.09 mg, $4.02 \mu \mathrm{mol}, 2.5$ eq. $)$ in anhydrous DMF ( $65 \mu \mathrm{L})$ and DIPEA $(2.13 \mu \mathrm{L}, 12.9 \mu \mathrm{mol}, 8$ eq.). The mixture was stirred at $25^{\circ} \mathrm{C}$ for $30 \mathrm{~min}$ and then were added PYBOP $(2.09 \mathrm{mg}, 4.02 \mu \mathrm{mol}, 2.5$ eq. $)$ and DIPEA $\left(2.13 \mu \mathrm{L}, 12.9 \mu \mathrm{mol}, 8\right.$ eq.). The mixture was stirred at $25^{\circ} \mathrm{C}$ for $2 \mathrm{~h}$ and the product was then isolated by semi-preparative HPLC using a linear gradient of $20-60 \%$ ACN $\left(0.1 \%\right.$ v/v TFA) in $\mathrm{H}_{2} \mathrm{O}(0.1 \% \mathrm{v} / \mathrm{v}$ TFA) in $30 \mathrm{~min}$ to afford after lyophilization a black purple solid (1.3 $\mathrm{mg}, 71 \%)$. $\mathrm{HPLC}_{\mathrm{R}}=5.39 \mathrm{~min}$ (> 95\% purity $[220.8 \mathrm{~nm}]$ ). HRMS (ESI) calcd for $\mathrm{C}_{56} \mathrm{H}_{70} \mathrm{ClFN}_{8} \mathrm{O}_{14}[\mathrm{M}+2 \mathrm{H}]^{2+} / 2$ : 566.2342 , found: 566.2341 .

Pf-PEG ${ }_{12}$-NR. To a solution of $8 \mathbf{c}$ (3.40 mg, $3.25 \mu \mathrm{mol}, 1.1$ eq.) in anhydrous DMF ( $\left.290 \mu \mathrm{L}\right)$ were added 4 (1.16 mg, $2.96 \mu$ mol, 1 eq.), PYBOP (4.38 mg, $8.42 \mu \mathrm{mol}, 2.6$ eq.) and DIPEA (4.29 $\mu \mathrm{L}, 26.0$ $\mu \mathrm{mol}, 8$ eq.). The mixture was stirred at $25{ }^{\circ} \mathrm{C}$ for $30 \mathrm{~min}$ and the product was then isolated by semipreparative HPLC using a linear gradient of $20-55 \%$ ACN $\left(0.1 \%\right.$ v/v TFA) in $\mathrm{H}_{2} \mathrm{O}(0.1 \% \mathrm{v} / \mathrm{v}$ TFA) in $30 \mathrm{~min}$ to afford after lyophilization a dark purple solid (1.50 mg, 39\%). HPLC $\mathrm{t}_{\mathrm{R}}=5.37 \mathrm{~min}(>95 \%$ purity [220.8 nm]). HRMS (ESI) calcd for $\mathrm{C}_{64} \mathrm{H}_{86} \mathrm{ClFN}_{8} \mathrm{O}_{18}[\mathrm{M}+2 \mathrm{H}]^{2+} / 2: 654.2866$, found: 654.2871 .

Pf-PEG ${ }_{20}$-NR. To a solution of $\mathbf{8 d}(2.70 \mathrm{mg}, 1.93 \mu \mathrm{mol}, 1$ eq.) in anhydrous DMF (172 $\mu \mathrm{L})$ were added 4 (1.51 mg, $3.86 \mu \mathrm{mol}, 2$ eq.), PYBOP (7.53 mg, $14.5 \mu \mathrm{mol}, 7$ eq.) and DIPEA (10.2 $\mu \mathrm{L}, 61.7 \mu \mathrm{mol}, 32$ eq.). The mixture was stirred at $25{ }^{\circ} \mathrm{C}$ for $25 \mathrm{~h}$ and the product was then isolated by semi-preparative 
HPLC using a linear gradient of 20-60\% ACN $\left(0.1 \%\right.$ v/v TFA) in $\mathrm{H}_{2} \mathrm{O}(0.1 \% \mathrm{v} / \mathrm{v}$ TFA) to afford after lyophilization a dark purple solid $(1.60 \mathrm{mg}, 50 \%)$. HPLC $\mathrm{t}_{\mathrm{R}}=5.58 \mathrm{~min}(>95 \%$ purity $[220.8 \mathrm{~nm}])$. HRMS (ESI) calcd for $\mathrm{C}_{80} \mathrm{H}_{119} \mathrm{ClFN}_{8} \mathrm{O}_{26}[\mathrm{M}+3 \mathrm{H}]^{3+} / 3: 554.2583$, found: 554.2582.

\section{Absorption and Steady-State Fluorescence Measurements}

General information. The excitation wavelength was $520 \mathrm{~nm}$ and the recorded emission spectral range was $530-800 \mathrm{~nm}$. Unless specified, all fluorescence spectra were corrected for instrumental factors. The absorbance of sample solutions at the excitation wavelength were kept below 0.05 to avoid inner filter effects. Data treatment was performed using Origin software.

Determination of fluorescence quantum yields. Determination of relative fluorescence quantum yields (QY) was performed using Nile Red in 1,4-dioxane as a reference $(\mathrm{QY}=70 \%){ }^{44}$

Preparation of 1 mM DOPC/cholesterol (2:1) liposomes. To a solution of DOPC (667 $\mu \mathrm{L}, 5 \mathrm{mM})$ in $\mathrm{CHCl}_{3}$ was added a solution of cholesterol $(333 \mu \mathrm{L}, 5 \mathrm{mM})$ in $\mathrm{CHCl}_{3}$ and the solvent was slowly evaporated under reduced pressure. The obtained film was rehydrated with PBS (5 mL, pH 7.1 - 7.5), vortexed for $5 \mathrm{~min}$ and kept at $25^{\circ} \mathrm{C}$ for $30 \mathrm{~min}$. The suspension of multilamellar vesicles was extruded by using a Lipex Biomembranes extruder using a $0.2 \mu \mathrm{m}$ filter for 7 passages and then $0.1 \mu \mathrm{m}$ filter for 10 passages. This generates monodisperse LUVs were characterized by a mean diameter of $0.15 \mu \mathrm{m}$ as measured with a Malvern Zetamaster 300 particle size analyser.

Evaluation of non-specific interactions with liposomes. The $1 \mu \mathrm{M}$ solutions of the studied probes in PBS with increasing amounts of DOPC/cholesterol (2:1) liposomes were prepared as follows. $5 \mu \mathrm{L}$ of $0.2 \mathrm{mM}$ stock DMSO solution of a studied probe were added accordingly to $995 \mu \mathrm{L}, 993 \mu \mathrm{L}, 991 \mu \mathrm{L}$, $985 \mu \mathrm{L}, 975 \mu \mathrm{L}, 945 \mu \mathrm{L}, 895 \mu \mathrm{L}$ and $795 \mu \mathrm{L}$ of PBS. Then $0 \mu \mathrm{L}, 2 \mu \mathrm{L}, 4 \mu \mathrm{L}, 10 \mu \mathrm{L}, 20 \mu \mathrm{L}, 50 \mu \mathrm{L}, 100$ $\mu \mathrm{L}$ and $200 \mu \mathrm{L}$ of $1 \mathrm{mM}$ DOPC/cholesterol (2:1) liposomes were respectively added and the solutions were carefully mixed.

Evaluation of non-specific interactions with BSA. The titrations of the studied probes with BSA were performed as follows. $1 \mu \mathrm{M}$ solution of the studied probes in PBS were prepared by diluting $5 \mu \mathrm{L}$ of 0.2 mM DMSO stock solutions in $995 \mu \mathrm{L}$ of PBS. Then successively $5 \mu \mathrm{L}, 5 \mu \mathrm{L}, 15 \mu \mathrm{L}, 25 \mu \mathrm{L}, 60 \mu \mathrm{L}$ of $0.2 \mathrm{mM}$ stock solution of BSA in PBS were added and the solutions were carefully mixed.

RTG calculation for Pf-PEG ${ }_{20}$-NR in solutions. First, the corrected fluorescence spectra were integrated from 530 to $600 \mathrm{~nm}$ ("green" channel) and from $600 \mathrm{~nm}$ to $700 \mathrm{~nm}$ ("red" channel). RTG was calculated as a ratio of the integral fluorescence in the "red" channel to the integral fluorescence in the "green" channel.

\section{Functional Characterisation of the OTR ligands}

Antagonist properties of the OTR ligands were determined by measuring their capacities to inhibit oxytocin-induced intracellular $\mathrm{Ca}^{2+}$ release. HEK293 cells stably overexpressing the OTR were first incubated with $5 \mu \mathrm{M}$ of Indo-1 AM in HEPES buffer (10 mM HEPES, $137.5 \mathrm{mM} \mathrm{NaCl}, 1.25 \mathrm{mM}$ $\mathrm{MgCl}_{2}, 1.25 \mathrm{mM} \mathrm{CaCl}_{2}, 6 \mathrm{mM} \mathrm{KCl}, 0.4 \mathrm{mM} \mathrm{NaH}_{2} \mathrm{PO}_{4}$ and $5.6 \mathrm{mM}$ glucose, $\mathrm{pH}$ 7.4) supplemented with $0.1 \%$ BSA for 45 minutes at $37{ }^{\circ} \mathrm{C}$ and $5 \% \mathrm{CO}_{2}$. The cells were then washed, resuspended in HEPES buffer supplemented with $0.1 \%$ BSA buffer, seeded into 384 well polystyrene plates (Greiner 781091) 
at 50000 cells/well and then centrifuged for $5 \mathrm{~min}$ at $800 \mathrm{rpm}$. Addition of compounds was performed using the FlexStation ${ }^{\circledR} 3$ automated pipettor. Compounds were tested at concentrations from $0.3 \mathrm{pM}$ to $3 \mu \mathrm{M}$ in the presence of $10 \mathrm{nM}$ of oxytocin. Intracellular $\mathrm{Ca}^{2+}$ release measurements were performed by monitoring the fluorescence of Indo-1 using a FlexStation ${ }^{\circledR} 3$ microplate reader (Molecular Devices Corp.). Excitation was set at $338 \mathrm{~nm}$, emissions were recorded at $401 \mathrm{~nm}$ and $475 \mathrm{~nm}$ at $25{ }^{\circ} \mathrm{C}$. Fluorescence emission ratio $401 \mathrm{~nm} / 475 \mathrm{~nm}$ was calculated in order to follow the calcium release. In order to assess the maximum calcium level, addition of digitonin (Sigma Aldrich) at $100 \mu \mathrm{M}$ was performed $110 \mathrm{~s}$ after the addition of the compounds. Dose-response curves were obtained by plotting the normalized signal of calcium release against the logarithmic values of compound concentration. The half maximal inhibitory concentration $\left(\mathrm{IC}_{50}\right)$ were calculated using GraphPad Prism software. Data resulted from two independent experiments performed in duplicate. Values are means \pm SEM.

\section{Fluorescence Confocal Microscopy}

Cell lines and culture conditions. HEK293 cells stably overexpressing the OTR were cultured in Eagle's minimal essential medium (MEM, Invitrogen 21090) with 10\% FBS, $100 \mathrm{U} / \mathrm{mL}$ of penicillin, $100 \mu \mathrm{g} / \mathrm{mL}$ of streptomycin, $2 \mathrm{mM}$ of glutamine and $500 \mu \mathrm{g} / \mathrm{mL}$ of $\mathrm{G} 418$ at $37{ }^{\circ} \mathrm{C}$ in a humidified $5 \%$ $\mathrm{CO}_{2}$ atmosphere. $70-80 \%$ cell confluence was maintained by removal of a portion of the culture and replacement with fresh medium twice a week. Cells were seeded into $35 \mathrm{~mm}$ ibiTreat $\mu$-dish (IBiDi) at 40000 cells per dish 3 days before imaging.

Live-cell no-wash OTR imaging. The culture medium was removed, the cells were washed with PBS and incubated with a $1 \mu \mathrm{g} / \mathrm{mL}$ solution of Hoechst 33342 in MEM for $15 \mathrm{~min}$ at $37^{\circ} \mathrm{C}$. The medium was removed, the cells were washed with PBS and a $10 \mathrm{nM}$ solution of the studied probe in PBS or a mixture of $10 \mathrm{nM}$ of the studied probe and $2 \mu \mathrm{M}$ of carbetocin in PBS were added. The cells were incubated for $20 \mathrm{~min}$ at $37{ }^{\circ} \mathrm{C}$ prior to the imaging. The imaging was performed at $22{ }^{\circ} \mathrm{C}$. Nile Red was excited with a $488 \mathrm{~nm} 10 \mathrm{~mW}$ laser at $80 \%$ intensity and detected at $570-630 \mathrm{~nm}$. Hoechst 33342 was excited with a $405 \mathrm{~nm} 25 \mathrm{~mW}$ laser at $10 \%$ intensity and detected at $430-480 \mathrm{~nm}$. The pinhole was set to 1 airy unit. The images were acquired at 1.5x magnification as a mean of 2 scans in 1024x1024 size. All images were processed with ImageJ. An additional 2x magnification was applied upon processing. The same brightness and contrast parameters for the Nile Red channel were applied to all the images.

MBCD treatments. The culture medium was removed, the cells were washed with Opti-MEM (no phenol red) and incubated with a freshly prepared $5 \mathrm{mM}$ solution of $\mathrm{M} \beta \mathrm{CD}$ in Opti-MEM (no phenol red) for $30 \mathrm{~min}$ at $37{ }^{\circ} \mathrm{C}$. The cells were then washed with Opti-MEM (no phenol red) and incubated with corresponding probes.

Ratiometric confocal microscopy imaging. The culture medium was removed, the cells were washed with Opti-MEM (no phenol red) and incubated with $20 \mathrm{nM}$ solutions of the studied probes in Opti-MEM (no phenol red) for $20 \mathrm{~min}$ at $37^{\circ} \mathrm{C}$. The imaging was performed at $22{ }^{\circ} \mathrm{C}$. Nile Red was excited with a $488 \mathrm{~nm} 10 \mathrm{~mW}$ laser at 30\% (Pf-PEG 4 -NR), 50\% (Pf-PEG $-\mathrm{NR}$ ) or $80 \%$ (for other probes). The fluorescence was collected from $500 \mathrm{~nm}$ to $600 \mathrm{~nm}$ ("green" channel C1) and from $600 \mathrm{~nm}$ to $700 \mathrm{~nm}$ ("red" channel C2). Images were acquired at $1.5 \mathrm{x}$ magnification in $512 \times 512$ size, 20 scans in each channel. All images were processed with ImageJ. Fluorescence intensity in each channel was averaged using z-stack projection. The mean of grey values of background signal was subtracted in both channels. Membrane ROI were created using the "Otsu" threshold. RTG values of the cell membrane were calculated by dividing the mean of grey values in the obtained masks in $\mathrm{C} 2$ by that in $\mathrm{C} 1$. The ratiometric 
confocal microscopy images were generated using the ImageJ macros "Ratio Intensity color Version 2.5" (developed by Romain Vauchelles, UMR 7213) that divides background-subtracted image of the "red" channel bybackground-subtracted image of the "green" channel. For each pixel, a pseudocolor scale is used for coding the RTG ratio.

\section{Acknowledgements}

This work was supported by the LabEx MEDALIS (ANR-10-LABX-0034 and the Attractivity Grant), Pierre Fabre, the Centre National de la Recherche Scientifique, the University of Strasbourg. F.H. was supported by a fellowship from Pierre Fabre and the LabEx MEDALIS. We are grateful to Sophie Gioria (Plate-forme de Chimie Biologique Intégrative de Strasbourg, UMS3286) for the assistance in cell culture experiments, Dr. Delphine Garnier and Dr. Estefania Oliva (PACSI platform GDS3670) for mass spectrometry and NMR spectroscopy and Dr. Dmytro Dziuba for fruitful suggestions and proofreading the manuscript.

Keywords: fluorescent probes $\bullet$ fluorogenic dyes $\bullet$ turn-on probes $\bullet$ cell imaging $\bullet$ GPCR

\section{References}

(1) Hauser, A. S.; Attwood, M. M.; Rask-Andersen, M.; Schiöth, H. B.; Gloriam, D. E. Trends in GPCR Drug Discovery: New Agents, Targets and Indications. Nat Rev Drug Discov 2017, 16 (12), 829-842. https://doi.org/10.1038/nrd.2017.178.

(2) Santos, R.; Ursu, O.; Gaulton, A.; Bento, A. P.; Donadi, R. S.; Bologa, C. G.; Karlsson, A.; AlLazikani, B.; Hersey, A.; Oprea, T. I.; Overington, J. P. A Comprehensive Map of Molecular Drug Targets. Nat Rev Drug Discov 2017, 16 (1), 19-34. https://doi.org/10.1038/nrd.2016.230.

(3) Davenport, A. P.; Scully, C. C. G.; de Graaf, C.; Brown, A. J. H.; Maguire, J. J. Advances in Therapeutic Peptides Targeting G Protein-Coupled Receptors. Nat Rev Drug Discov 2020, 19 (6), 389-413. https://doi.org/10.1038/s41573-020-0062-z.

(4) Sriram, K.; Insel, P. A. G Protein-Coupled Receptors as Targets for Approved Drugs: How Many Targets and How Many Drugs? Mol Pharmacol 2018, 93 (4), 251-258. https://doi.org/10.1124/mol.117.111062.

(5) Hilger, D.; Masureel, M.; Kobilka, B. K. Structure and Dynamics of GPCR Signaling Complexes. Nat Struct Mol Biol 2018, 25 (1), 4-12. https://doi.org/10.1038/s41594-017-0011-7.

(6) Weis, W. I.; Kobilka, B. K. The Molecular Basis of G Protein-Coupled Receptor Activation. Annu. Rev. Biochem. 2018, 87 (1), 897-919. https://doi.org/10.1146/annurev-biochem060614-033910.

(7) Congreve, M.; de Graaf, C.; Swain, N. A.; Tate, C. G. Impact of GPCR Structures on Drug Discovery. Cell 2020, 181 (1), 81-91. https://doi.org/10.1016/j.cell.2020.03.003.

(8) Lingwood, D.; Simons, K. Lipid Rafts As a Membrane-Organizing Principle. Science 2010, 327 (5961), 46-50. https://doi.org/10.1126/science.1174621.

(9) Sezgin, E.; Levental, I.; Mayor, S.; Eggeling, C. The Mystery of Membrane Organization: Composition, Regulation and Roles of Lipid Rafts. Nat Rev Mol Cell Biol 2017, 18 (6), 361-374. https://doi.org/10.1038/nrm.2017.16.

(10) Wiseman, D. N.; Otchere, A.; Patel, J. H.; Uddin, R.; Pollock, N. L.; Routledge, S. J.; Rothnie, A. J.; Slack, C.; Poyner, D. R.; Bill, R. M.; Goddard, A. D. Expression and Purification of Recombinant G Protein-Coupled Receptors: A Review. Protein Expression and Purification 2020, 167, 105524. https://doi.org/10.1016/j.pep.2019.105524. 
(11) Wacker, D.; Stevens, R. C.; Roth, B. L. How Ligands Illuminate GPCR Molecular Pharmacology. Cell 2017, 170 (3), 414-427. https://doi.org/10.1016/j.cell.2017.07.009.

(12) Huber, T.; Sakmar, T. P. Chemical Biology Methods for Investigating G Protein-Coupled Receptor Signaling. Chemistry \& Biology 2014, 21 (9), 1224-1237. https://doi.org/10.1016/j.chembiol.2014.08.009.

(13) Grunbeck, A.; Sakmar, T. P. Probing G Protein-Coupled Receptor-Ligand Interactions with Targeted Photoactivatable Cross-Linkers. Biochemistry 2013, 52 (48), 8625-8632. https://doi.org/10.1021/bi401300y.

(14) Ciruela, F.; Jacobson, K. A.; Fernández-Dueñas, V. Portraying G Protein-Coupled Receptors with Fluorescent Ligands. ACS Chem. Biol. 2014, 9 (9), 1918-1928. https://doi.org/10.1021/cb5004042.

(15) Ma, Z.; Du, L.; Li, M. Toward Fluorescent Probes for G-Protein-Coupled Receptors (GPCRs): Miniperspective. J. Med. Chem. 2014, 57 (20), 8187-8203.

https://doi.org/10.1021/jm401823z.

(16) Soave, M.; Briddon, S. J.; Hill, S. J.; Stoddart, L. A. Fluorescent Ligands: Bringing Light to Emerging GPCR Paradigms. Br J Pharmacol 2020, 177 (5), 978-991.

https://doi.org/10.1111/bph.14953.

(17) Tian, H.; Fürstenberg, A.; Huber, T. Labeling and Single-Molecule Methods To Monitor G Protein-Coupled Receptor Dynamics. Chem. Rev. 2017, 117 (1), 186-245. https://doi.org/10.1021/acs.chemrev.6b00084.

(18) Demchenko, A. P.; Mély, Y.; Duportail, G.; Klymchenko, A. S. Monitoring Biophysical Properties of Lipid Membranes by Environment-Sensitive Fluorescent Probes. Biophysical Journal 2009, 96 (9), 3461-3470. https://doi.org/10.1016/j.bpj.2009.02.012.

(19) Klymchenko, A. S. Solvatochromic and Fluorogenic Dyes as Environment-Sensitive Probes: Design and Biological Applications. Acc. Chem. Res. 2017, 50 (2), 366-375. https://doi.org/10.1021/acs.accounts.6b00517.

(20) Dijkman, P. M.; Watts, A. Lipid Modulation of Early G Protein-Coupled Receptor Signalling Events. Biochimica et Biophysica Acta (BBA) - Biomembranes 2015, 1848 (11), 2889-2897. https://doi.org/10.1016/j.bbamem.2015.08.004.

(21) Mondal, S.; Khelashvili, G.; Johner, N.; Weinstein, H. How the Dynamic Properties and Functional Mechanisms of GPCRs Are Modulated by Their Coupling to the Membrane Environment. In G Protein-Coupled Receptors - Modeling and Simulation; Filizola, M., Ed.; Advances in Experimental Medicine and Biology; Springer Netherlands: Dordrecht, 2014; Vol. 796, pp 55-74. https://doi.org/10.1007/978-94-007-7423-0_4.

(22) Gahbauer, S.; Böckmann, R. A. Comprehensive Characterization of Lipid-Guided G ProteinCoupled Receptor Dimerization. J. Phys. Chem. B 2020, 124 (14), 2823-2834. https://doi.org/10.1021/acs.jpcb.0c00062.

(23) Gahbauer, S.; Böckmann, R. A. Membrane-Mediated Oligomerization of G Protein Coupled Receptors and Its Implications for GPCR Function. Front. Physiol. 2016, 7. https://doi.org/10.3389/fphys.2016.00494.

(24) Bolivar, J. H.; Muñoz-García, J. C.; Castro-Dopico, T.; Dijkman, P. M.; Stansfeld, P. J.; Watts, A. Interaction of Lipids with the Neurotensin Receptor 1. Biochimica et Biophysica Acta (BBA) Biomembranes 2016, 1858 (6), 1278-1287. https://doi.org/10.1016/j.bbamem.2016.02.032.

(25) Yoshida, K.; Nagatoishi, S.; Kuroda, D.; Suzuki, N.; Murata, T.; Tsumoto, K. Phospholipid Membrane Fluidity Alters Ligand Binding Activity of a G Protein-Coupled Receptor by Shifting the Conformational Equilibrium. Biochemistry 2019, 58 (6), 504-508. https://doi.org/10.1021/acs.biochem.8b01194.

(26) Becher, A.; Mcllhinney, R. A. J. Consequences of Lipid Raft Association on G-Protein-Coupled Receptor Function. Biochemical Society Symposia 2005, 72, 151-164. https://doi.org/10.1042/bss0720151. 
(27) Levental, I.; Levental, K. R.; Heberle, F. A. Lipid Rafts: Controversies Resolved, Mysteries Remain. Trends in Cell Biology 2020, 30 (5), 341-353.

https://doi.org/10.1016/j.tcb.2020.01.009.

(28) Dietrich, C.; Bagatolli, L. A.; Volovyk, Z. N.; Thompson, N. L.; Levi, M.; Jacobson, K.; Gratton, E. Lipid Rafts Reconstituted in Model Membranes. Biophysical Journal 2001, 80 (3), 1417-1428. https://doi.org/10.1016/S0006-3495(01)76114-0.

(29) Jin, L.; Millard, A. C.; Wuskell, J. P.; Dong, X.; Wu, D.; Clark, H. A.; Loew, L. M. Characterization and Application of a New Optical Probe for Membrane Lipid Domains. Biophysical Journal 2006, 90 (7), 2563-2575. https://doi.org/10.1529/biophysj.105.072884.

(30) Kucherak, O. A.; Oncul, S.; Darwich, Z.; Yushchenko, D. A.; Arntz, Y.; Didier, P.; Mély, Y.; Klymchenko, A. S. Switchable Nile Red-Based Probe for Cholesterol and Lipid Order at the Outer Leaflet of Biomembranes. J. Am. Chem. Soc. 2010, 132 (13), 4907-4916. https://doi.org/10.1021/ja100351w.

(31) Danylchuk, D. I.; Moon, S.; Xu, K.; Klymchenko, A. S. Switchable Solvatochromic Probes for Live-Cell Super-resolution Imaging of Plasma Membrane Organization. Angew. Chem. Int. Ed. 2019, 58 (42), 14920-14924. https://doi.org/10.1002/anie.201907690.

(32) Klymchenko, A. S.; Kreder, R. Fluorescent Probes for Lipid Rafts: From Model Membranes to Living Cells. Chemistry \& Biology 2014, 21 (1), 97-113.

https://doi.org/10.1016/j.chembiol.2013.11.009.

(33) Buenaventura, T.; Bitsi, S.; Laughlin, W. E.; Burgoyne, T.; Lyu, Z.; Oqua, A. I.; Norman, H.; McGlone, E. R.; Klymchenko, A. S.; Corrêa, I. R.; Walker, A.; Inoue, A.; Hanyaloglu, A.; Grimes, J.; Koszegi, Z.; Calebiro, D.; Rutter, G. A.; Bloom, S. R.; Jones, B.; Tomas, A. Agonist-Induced Membrane Nanodomain Clustering Drives GLP-1 Receptor Responses in Pancreatic Beta Cells. PLoS Biol 2019, 17 (8), e3000097. https://doi.org/10.1371/journal.pbio.3000097.

(34) Karpenko, I. A.; Kreder, R.; Valencia, C.; Villa, P.; Mendre, C.; Mouillac, B.; Mély, Y.; Hibert, M.; Bonnet, D.; Klymchenko, A. S. Red Fluorescent Turn-On Ligands for Imaging and Quantifying $G$ Protein-Coupled Receptors in Living Cells. ChemBioChem 2014, 15 (3), 359-363. https://doi.org/10.1002/cbic.201300738.

(35) Darwich, Z.; Klymchenko, A. S.; Dujardin, D.; Mély, Y. Imaging Lipid Order Changes in Endosome Membranes of Live Cells by Using a Nile Red-Based Membrane Probe. RSC Adv. 2014, 4 (17), 8481-8488. https://doi.org/10.1039/C3RA47181K.

(36) Kreder, R.; Pyrshev, K. A.; Darwich, Z.; Kucherak, O. A.; Mély, Y.; Klymchenko, A. S. Solvatochromic Nile Red Probes with FRET Quencher Reveal Lipid Order Heterogeneity in Living and Apoptotic Cells. ACS Chem. Biol. 2015, 10 (6), 1435-1442. https://doi.org/10.1021/cb500922m.

(37) Brown, A.; Brown, T. B.; Calabrese, A.; Ellis, D.; Puhalo, N.; Ralph, M.; Watson, L. Triazole Oxytocin Antagonists: Identification of an Aryloxyazetidine Replacement for a Biaryl Substituent. Bioorganic \& Medicinal Chemistry Letters 2010, 20 (2), 516-520. https://doi.org/10.1016/j.bmcl.2009.11.097.

(38) Karpenko, I. A.; Margathe, J.-F.; Rodriguez, T.; Pflimlin, E.; Dupuis, E.; Hibert, M.; Durroux, T.; Bonnet, D. Selective Nonpeptidic Fluorescent Ligands for Oxytocin Receptor: Design, Synthesis, and Application to Time-Resolved FRET Binding Assay. J. Med. Chem. 2015, 58 (5), 2547-2552. https://doi.org/10.1021/jm501395b.

(39) Briggs, M. S. J.; Bruce, I.; Miller, J. N.; Moody, C. J.; Simmonds, A. C.; Swann, E. Synthesis of Functionalised Fluorescent Dyes and Their Coupling to Amines and Amino Acids. J. Chem. Soc., Perkin Trans. 1 1997, No. 7, 1051-1058. https://doi.org/10.1039/a605012c.

(40) Martin-Brown, S. A.; Fu, Y.; Saroja, G.; Collinson, M. M.; Higgins, D. A. Single-Molecule Studies of Diffusion by Oligomer-Bound Dyes in Organically Modified Sol-Gel-Derived Silicate Films. Anal. Chem. 2005, 77 (2), 486-494. https://doi.org/10.1021/ac0491511.

(41) Kashida, H.; Asanuma, H. Preparation of Supramolecular Chromophoric Assemblies Using a DNA Duplex. Phys. Chem. Chem. Phys. 2012, 14 (20), 7196. https://doi.org/10.1039/c2cp40520b. 
(42) Mukherjee, S.; Raghuraman, H.; Chattopadhyay, A. Membrane Localization and Dynamics of Nile Red: Effect of Cholesterol. Biochimica et Biophysica Acta (BBA) - Biomembranes 2007, 1768 (1), 59-66. https://doi.org/10.1016/j.bbamem.2006.07.010.

(43) Greenspan, P.; Mayer, E. P.; Fowler, S. D. Nile Red: A Selective Fluorescent Stain for Intracellular Lipid Droplets. The Journal of Cell Biology 1985, 100 (3), 965-973. https://doi.org/10.1083/jcb.100.3.965.

(44) Sackett, D. L.; Wolff, J. Nile Red as a Polarity-Sensitive Fluorescent Probe of Hydrophobic Protein Surfaces. Analytical Biochemistry 1987, 167 (2), 228-234. https://doi.org/10.1016/0003-2697(87)90157-6.

(45) Lampe, J. N.; Fernandez, C.; Nath, A.; Atkins, W. M. Nile Red Is a Fluorescent Allosteric Substrate of Cytochrome P450 3A4 ${ }^{\dagger}$. Biochemistry 2008, 47 (2), 509-516. https://doi.org/10.1021/bi7013807.

(46) Black, S. L.; Stanley, W. A.; Filipp, F. V.; Bhairo, M.; Verma, A.; Wichmann, O.; Sattler, M.; Wilmanns, M.; Schultz, C. Probing Lipid- and Drug-Binding Domains with Fluorescent Dyes. Bioorganic \& Medicinal Chemistry 2008, 16 (3), 1162-1173. https://doi.org/10.1016/j.bmc.2007.10.080.

(47) Ashoka, A. H.; Ashokkumar, P.; Kovtun, Y. P.; Klymchenko, A. S. Solvatochromic Near-Infrared Probe for Polarity Mapping of Biomembranes and Lipid Droplets in Cells under Stress. J. Phys. Chem. Lett. 2019, 10 (10), 2414-2421. https://doi.org/10.1021/acs.jpclett.9b00668.

(48) Waltenspühl, Y.; Schöppe, J.; Ehrenmann, J.; Kummer, L.; Plückthun, A. Crystal Structure of the Human Oxytocin Receptor. Sci. Adv. 2020, 6 (29), eabb5419. https://doi.org/10.1126/sciadv.abb5419.

(49) Mahammad, S.; Parmryd, I. Cholesterol Depletion Using Methyl- $\beta$-Cyclodextrin. In Methods in Membrane Lipids; Owen, D. M., Ed.; Springer New York: New York, NY, 2015; Vol. 1232, pp 91-102. https://doi.org/10.1007/978-1-4939-1752-5_8.

(50) Zhang, P.; Lindsay, S.; Manna, S.; Senapati, S. Linker Molecule for Multiplex Recognition by Atomic Force Microscopy (AFM). US 2017/0137389 Al, May 18, 2017. 